NOÉ SILVA é mestre em Letras pela

Universidade

M. V. Lomonóssov

de Moscou e doutor

em Literatura

Russa pela USP.

O escritor russo

Aleksandr Kuprin

em foto dos

anos 10

NOÉ SILVA
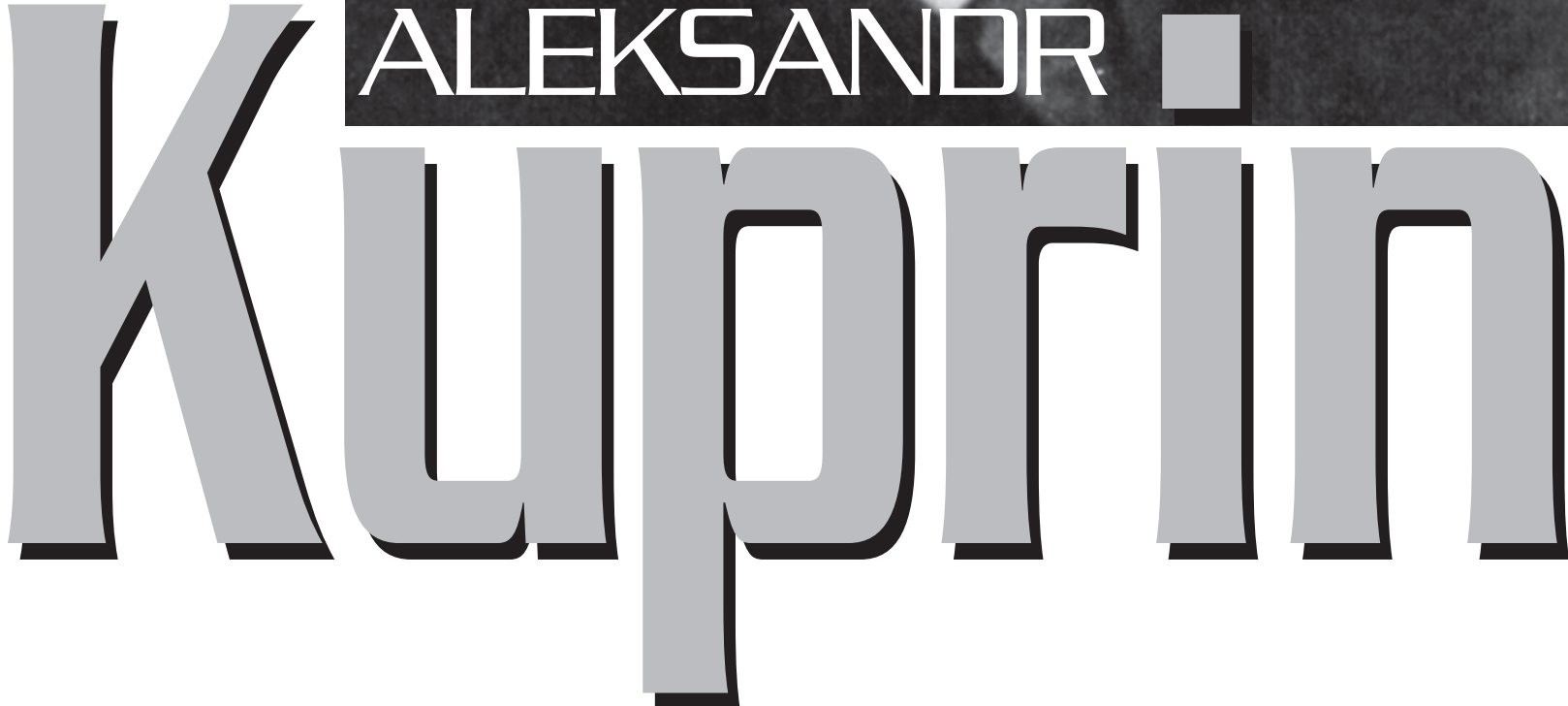


\section{0 talento}

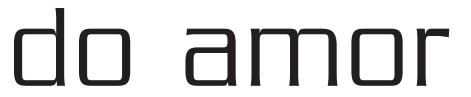

\section{à vida}

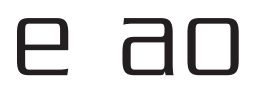

\section{próximo}
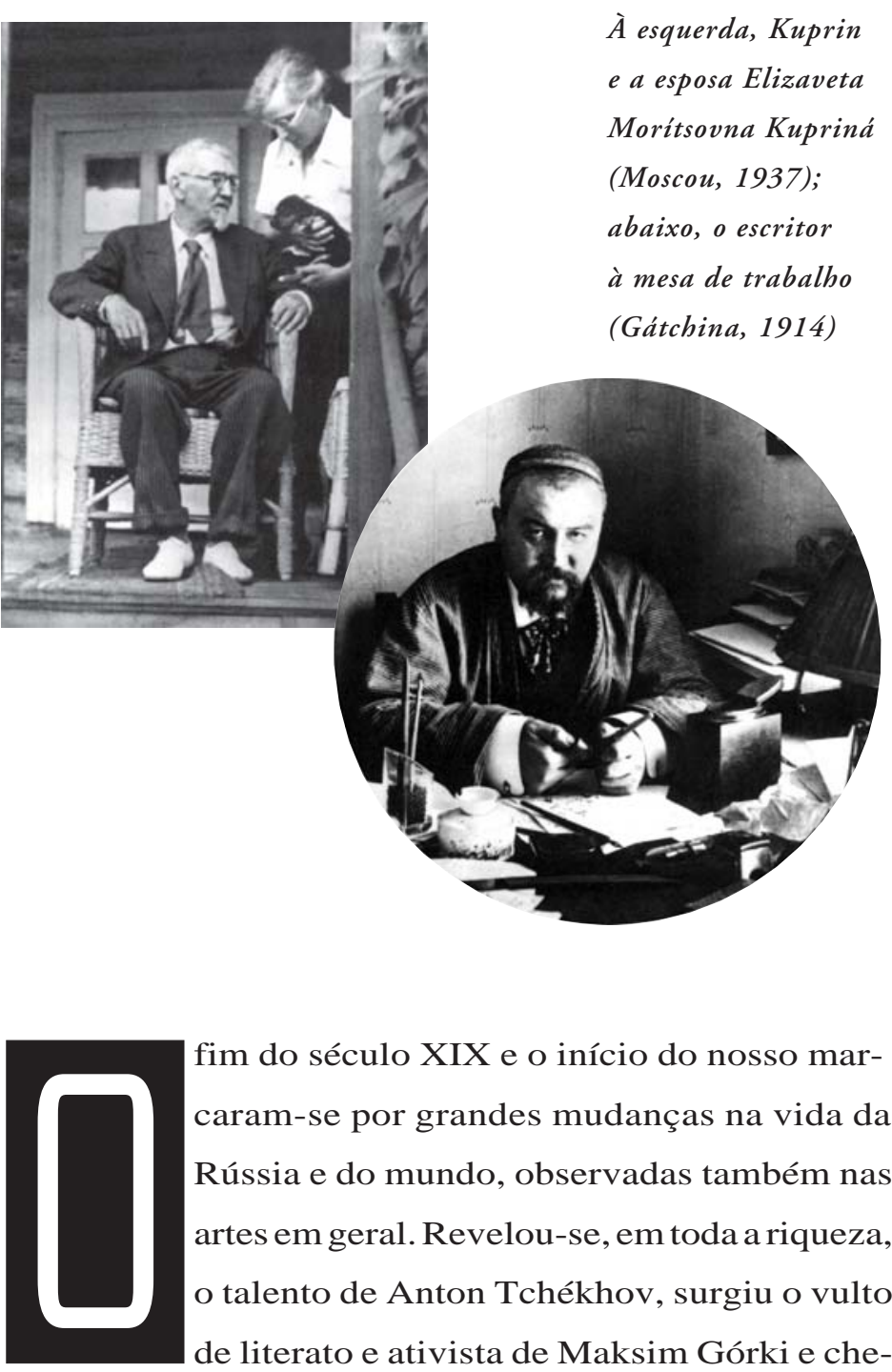

fim do século XIX e o início do nosso marcaram-se por grandes mudanças na vida da Rússia e do mundo, observadas também nas artes em geral. Revelou-se, em toda a riqueza, o talento de Anton Tchékhov, surgiu o vulto de literato e ativista de Maksim Górki e che-

gou a termo o caminho literário e terrestre de Lev Tolstói. Ao lado deles, havia uma plêiade de autores originais, como Dmítri Mámin-Sibiriak, Vladímir Korolénko, chamado "a consciência da Rússia”, Ivan Búnin, laureado com o Prêmio Nobel de Literatura em 1933, Leonid Andréev e Serguéi Serguéev-Tsénski.

Outra figura significativa dessa época foi Aleksandr Kuprin. Autor de várias obras-primas e homem tanto de idéias democráticas quanto de atitudes políticas equivocadas, seguiu a nobre tradição da literatura russa da intervenção direta do escritor, a tradição da sua consciência cívica e intransigência, da sua participação no desenvolvimento espiritual do povo, encaminhado todo ele para que a vida e as pessoas fossem melhores e mais puras. 
1 Kuprin costumava dizer que ao escrever, "roubava" sempre alguma coisa da mãe.

2 Liam-se capítulos seus em serões na casa de Lev Tolstói, e as descrições do tratamento dado aos soldados faziam este prorromper em lágrimas. Kuprin começou a escrever a obra em 1902. "Larguei o manuscrito várias vezes, achando que lhe faltava brilho, mas ao ler os capítulos prontos, entusiasmou-se e até chorou. Sem a confiança, que ele me deu, eu certamente não haveria concluído o meu romance." Citado por:A Vólkov, Tvórtchestvo A. I. Kupriná (A Obra de A. Kuprin), Moscou, 1981, p. 139. As forças progressistas da sociedade russa saudaram o aparecimento do livro, dedicado a Maksim Górki.

3 Um advogado de Odessa, amigo de Kuprin, contou-lh que um estivador, sujeito grandalhudo, batia na mãe. No mesmo dia, o escritor fo ao porto à procura do brutamontes e desafiou-o. Pouco tempo depois, a veIhinha apareceu no rio do jurista para agradecer a Aleksandr Ivánovitch. Conta Ksénia Aleksándrovna Kupriná, no livro Kuprin-moi otiéts (Kuprin, Meu Pai, Moscou, 1976), que viajava ele, certo $r$, quando um oficial de alta patente destratou uma moça do povo na sua presença. Kuprin deu um pescoção no homem e atirou-o por cima da borda do barco. Ainda ramente verossímil, impediu Kuprin de continuar a prestar exames para ingresso na Escola de Estado-Maior e determinou o fim da sua carreira militar.

4 Ótcherk: obra literária não muito extensa, constituída, fundamentalmente, da reprodução de fatos e acontecimentos reais, e da retratação de pessoas, vistas, como eles, diretamente na própria vida pelo autor.
Aleksandr Ivánovitch Kuprin nasceu a 7 de setembro de 1870 , em Narovtchát, província de Pénza, a algumas centenas de quilômetros a sudeste de Moscou. Quando tinha dois anos, morreu-lhe de cólera o pai, humilde funcionário público. Em 1874, mudou-se com a mãe e as duas irmãs para Moscou, onde se instalaram em um abrigo para viúvas. Teve, em Liubóv Alekséevna Kupriná, mulher forte, de espírito observador e linguajar colorido, a sua primeira mestra (1) e herdou muitos traços dela, como o grande amor à vida, a afabilidade, a tenacidade e a laboriosidade.

Em 1876, com a família em situação extremamente difícil, Liubóv Alekséevna matriculou Aleksandr como interno em uma escola para crianças órfãs. Ele ingressou, dois anos depois, no Segundo Ginásio Militar da cidade. Entrou a escrever versos mais ou menos aos 13 anos; eles desempenharam certo papel na formação de Kuprin como escritor e revelavam, pelo conteúdo e pela forma, a influência de alguns clássicos, como Alekséi K. Tolstói (1817-75) e Nikolai Nekrássov (1821-78).

Aos 18 anos, foi para a academia de oficiais. Em meio às aulas de pedagogos medíocres e ríspidos, havia as conferências inspiradas do professor de língua e letras pátrias. Precisamente na realidade sombria da caserna, meio hostil às relações verdadeiramente humanas entre as pessoas, nasceu, em Kuprin, o amor à literatura; em 1889, publicou o primeiro conto, "A Última Estréia".

Como alferes, seguiu, em 1890, para o povoado de Proskúrov, servindo em um regimento de infantaria do Dniepr. A torpeza dos costumes militares, a miséria do lugar e a vida da intelliguiéntsia da província causaram-lhe funda impressão. A denúncia do ambiente moral dos quartéis, constrangedor das pessoas inteligentes e honestas, apareceu já nas suas primeiras produções sérias, como a novela No Escuro (1893) e os contos "Em uma Noite Enluarada" (1893) e "O Inquérito” (1894). Este, com o seu pathos humanístico e a crítica ao absolutismo, intensificados em "O Sargento-mor do Exército" (1897), “Turno da Noite" (1899) e "Momento de Viragem" (1900), antecipou o tema da criação mais importante do escritor, "O Duelo" (1905) (2). Para Kuprin, expoente da filantropia combativa, o verdadeiro humanismo não se limitava ao preceito "Ama o semelhante como a ti próprio". A sua obra e vida afirmam: Deves defender o próximo de todas as coisas cruéis, tenebrosas, e de todas as ignomínias (3).

Em 1893, reformou-se do Exército. Deambulou de um lugar a outro, a ganhar a vida como trabalhador braçal, agrimensor, operário, plantador de tabaco, sacristão, tiradentes, pescador, cantor de coro e artista de teatro, e, boêmio, generoso e bem-humorado, conviveu com pessoas de todas as camadas sociais. Em agosto daquele ano, chegou a Kíev sem dinheiro algum. Empregou-se como repórter e publicou contos e artigos nos jornais e revistas da cidade. A sua atividade publicística nos anos 90, seguidora da orientação delineada já pelos versos da adolescência, refuta a tese dos críticos sobre o seu indiferentismo social e apolitismo; isso vê-se muito bem nos ótcherks (4) sobre o tema da produção, como “A Fábrica de Iúzov" (1896) e "Na Mina Principal" (1899). Esse gênero, cultivado por ele também no ciclo "Tipos Kievanos", de descrição de costumes, constituiu uma espécie de escola, em que ele compreendeu as leis da literatura realista e transformou a verdade da vida em verdade da arte. Os seus primeiros contos apresentavam traços do estilo do Kuprinpublicista: avidez de conhecimentos, interesse pelas pessoas, principalmente pelo destino das mais humildes, e tendência a basear a obra em fatos observados. A notoriedade veio-lhe com a novela Molok (1896), caracterizada por quadros expressivos do mundo dos mineiros da Bacia do Don e pelo tratamento maduro de problemas sociais e éticos da época posterior à reforma de 1861 (a libertação dos servos).

Pela primavera de 1900, começou a percorrer a Criméia, importantíssima na sua vida e obra; travou conhecimento com Anton Tchékhov, Ivan Búnin, Nikolai GárinMikhailóvski e outros literatos. Casou-se, em 1901, com Maria Kárlovna Davídova, oriunda de uma família abastada de Petersburgo. Descobriu Balaklava, vila de 
pescadores em uma enseada, cujo dia-a-dia retratou no ciclo de ótcherks Listrigóni (1907-11), penetrados de intenso e jubiloso sentimento da vida e escritos com a naturalidade e a liberdade, que denotam a verdadeira inspiração. Ao participar na arriscada labuta dos homens do mar, Kuprin obedeceu aos instintos da sua alma cândida e extrospectiva, atraída por aquele rude trabalho primicial, que, na região, constituía o princípio de todos os princípios da existência e, com a sua simplicidade aparente, ressumbrava um sentido profundo e eterno, pleno de encanto; a arte do escritor, feita de cor e lirismo, fundiu os homens e as coisas no mesmo fluido vital.

Demorou-se um tempo em Ialta, visitando quase diariamente a casa de Tchékhov; este acompanhou a gravidez da esposa e deulhe informações para o conto "No Circo" (1902) (5).

Em outubro de 1905, foi freqüentemente de Balaklava a Sevastópol, apresentando-se em auditórios com a leitura de trechos de "O Duelo", encontrou-se com marinheiros e sabia da iminência de uma rebelião. Permaneceu na cidade durante a insurreição do cruzador "Otchákov" (11 a 15 de novembro) e, em meio à repressão sangrenta aos sublevados e ao fuzilamento de centenas de pessoas, ajudou muitos insurretos a esconder-se na aldeia de Tchorgun, salvando-lhes a vida; esses fatos deram origem ao conto "A Lagarta" (1918). Pelas manifestações na imprensa e participação nos acontecimentos políticos, as autoridades obrigaram-no a mudar-se de Balaklava em dezembro daquele mesmo ano.

Kuprin teve sempre consciência muito clara do lado de quem devia estar. Daí, o seu desprezo às classes privilegiadas, as quais representou com ironia e sarcasmo, a exemplo das personagens anônimas do conto "Inebriamento" (1907) - todos esses “[...] parasitas, jogadores, concubinas, rostos barbeados pertencentes não se sabe a quem, caixeiros viajantes, agiotas da Bolsa, alcoviteiros, trampolineiros bem vestidos". Contrapôs, à imoralidade e frivolidade do mundo burguês, a integridade e nobreza das gentes humildes, como o velho tocador de realejo e o menino acrobata de "OCão de Águas Branco" (1904), amigos seus, que perambulavam pela Criméia, em companhia de um cão, e apresentavam espetáculos de rua. Kuprin, incapaz de levar uma existência regrada, tinha muitos atritos com a esposa, que se esforçava por atraí-lo para o seu meio, de pessoas ciosas da sua posição na sociedade.

Escrever basicamente apenas sobre o que presenciou e sentiu constitui uma das características fundamentais de Kuprin; a fisionomia do homem e do meio sai das suas obras com o cunho de quem viu e conheceu intimamente tudo quanto descreve. Ele consagrou toda a sua criação ao povo, aos que conhecia pelo nome, recordava pelo sorriso, modo de falar, pelas canções e até pelo cheiro (6). Também procurava avidamente o convívio de quem vivia do suor do rosto, pessoas de mãos calosas, os seres mais simples e essenciais da terra. Com esse espírito, foi algum tempo a uma cervejaria de Odessa, riu e bebeu com os seus freqüentadores, na maioria trabalhadores do porto, operários, pescadores, mergulhadores e marinheiros. Um ano depois, publicou o conto "Hambrinus" (1907), em que celebrava a casa e o violinista Sachka e reiterava a sua simpatia a todos os que, com a sua vida difícil e, às vezes, até torta, negavam ostensivamente os valores pequeno-burgueses e podiam entrar na luta contra as iniqüidades sociais. Essa pequena obra-prima dá toda a medida da afirmação da vida como parcela da arte de Kuprin. Para ele, ser artista significava, primordialmente, sentir a alegria de estar vivo, não deixar nunca de admirar o belo e de encontrá-lo nas coisas mais comuns, e tirar um canto à luz e ao bem, ainda que do ambiente penumbroso e enfumaçado de um botequim e da companhia de sujeitos de costumes desenfreados e língua viperina.

Ele andou com as melhores companhias e também com as piores, freqüentando todos os lugares possíveis; isso forneceu-lhe variada galeria de tipos, material precioso, que o seu talento amoldou com habilidade, infundindo-lhe o tom da tragédia ou a tônica sadia do gosto de viver e da força ante os lances adversos do destino. Ele não se deixava atrair por pensamentos abstratos e
5 Na verdade, Kuprin escre-
veu-o na casa de
Tchékhov, que, logo após
a publicação, mandou-lhe
umtelegrama: “Informo-lhe
que o seu conto foi lido por
L. N. Tolstói e Ihe agradou
muito". Opróprio Tchékhov
entusiasmou-se: “'No Cir-
co' é uma coisa livre, ingê-
nua, talentosa, indubi-
tavelmente escrita poruma
pessoa entendida...". A. P.
Tchékhov, O Literatúrie
(Sobre Literatura), Mos-
cou, 1955, p. 243.
Vários contemporâneos de
Kuprin falam da sua capa-
cidade de sentir odores e
distingui-los, o que a sua
obra confirma plenamente.
Somente em Ivan Búnin
encontrava rival à altura, e
os dois punham-se alegre-
mente a ver quem definia
melhor o cheiro da arena
dos circos, de uma igreja
católica nas matinas da
Páscoa, etc. Contam, ain-
da, que Kuprin tinha o há-
bito de cheirar as pessoas
e era capaz de, pelo sim-
ples olfato, determinar as
suas virtudes e defeitos. 
Na outra página,

Kuprin em um

balão (1911)
7 K. Tchukóvski, "Kuprin", in A. I. Kuprin, Sobránie sotchiniénia (Obras Reunidas), oito tomos, Moscou, 1964 , t. 1 , p. 7

8 Lev Tolstói acompanhava atentamente a obra de Kuprin, gostava muito do ceus contos, particularmende "Allez!. "Quão compacto é tudo nele! E maravilhoso. E como é que ele não esquece que a calçada brilhava, e todas as outras minúcias. E, mais importané de que maneira tão $p$ douradura postiça de civilização e falso cristianismo [...] Ele tem um talento autêntico, maravilhoso, genuíno". Lev Tolstói vospominániakh usomiénnikoviak sovrériennikov (Lev Tolstoi nas Reminiscencias dos Contemporâneos) Moscou, 1955, t. 2, p. 105

9 Maksim Górki escreveu a E. K. Malinóvskaia: "Que coisa magnífica 'O Bracelete sa magnifica 'O Bracelete . Granad... Que maravilha! Eu estou contente, hoje é dia de festa para mim! Começa uma literatura boa!". V. Afanássiev. Aleksandr Ivánovitch Kuprin, Moscou, 1972, p. 158. especulativos e centrava a atenção nas idéias enraizadas no mais profundo das relações humanas e nas necessidades mais imperiosas do indivíduo. Fosse para onde fosse, a ganhar a vida como jornalista e escritor e a usar a sabedoria acumulada pela experiência, Kuprin encontrava sempre o ambiente necessário à inspiração e à sua natureza vivaz e transbordante. Assim o recorda Kornéi Tchukóvski, então poeta iniciante e testemunha de muitas brincadeiras suas:

“Aleksandr Ivánovitch causava a impressão de pessoa saudável até demais: o pescoço era como de boi, o peito e as costas, como de um carregador; atarracado, largo de ombros, ele levantava com facilidade uma poltrona antiga e pesadíssima por um pé da frente. A gravata e o paletó não combinavam com a sua figura musculosa: ele parecia um ferreiro, que se houvesse ataviado por ocasião de um feriado. $\mathrm{O}$ seu rosto era largo, o nariz como que levemente fraturado; os olhos, estreitos, sempre semicerrados, olhos incansáveis e espertos, absorviam as mínimas coisas da vida circundante" (7).

Kuprin cultuava a beleza e a pujança físicas, pois ele próprio, além de freqüentar circos desde criança, praticava vários desportos, entre eles, o boxe, a natação, a ginástica e a luta greco-romana, e gostava de atividades que exigissem vigor e destreza e envolvessem risco, como voar em balões e nos primeiros modelos de avião, sair ao mar alto com pescadores e mergulhar de escafandro. Essa verdadeira sede de sensações e conhecimentos levava-o a querer saber tudo das pessoas das mais variadas atividades e do seu ofício, fossem elas mineiros, artistas, músicos, ladrões de cavalo, banqueiros, jogadores ou monges, e a ir a assembléias de empregados do comércio, passar dias em acampamentos de ciganos, gastar horas na observação de animais e até entrar em jaulas de tigres com os seus amigos domadores.

Kuprin parecia ter pressa de viver, de gastar a energia acumulada em si, e tal perenidade na dissipação de forças talvez haja encontrado a sua maior expressão no amor, ao domínio do qual, em regra, as suas perso- nagens se entregam totalmente. Tal qual a vida militar, a comoção amorosa ocupou lugar importante na sua obra; ela ajudou o escritor a afirmar os seus ideais humanísticos, como o valor estético e moral da vida terrena, a capacidade humana para as atitudes mais nobres e abnegadas, e, por outro lado, a revelar a marca sombria das contradições da época no mundo interior do indivíduo.

O amor, correspondido ("Oléssia", 1898) ou não (“Allez!", 1897; e outros) (8), sempre morre porque o encontro das pessoas ocorre em circunstâncias decorrentes de fatores sociais, que excluem a felicidade. Kuprin produziu duas novelas altamente poéticas sobre o tema - Sulamita (1908), bafejada pelas lendas orientais, e $O$ Bracelete de Granadas (1911), história real um tanto melodramatizada mas, ainda assim, uma obra-prima (9) -, celebrando impulsos sublimes em uma época em que uma literatura vulgar inundava o mercado.

Kuprin relacionava a busca da beleza com os grandes e elevados sentimentos e também com a aspiração à Natureza. Conseguia penetrar o mundo da Natura e criar vívidas e verazes imagens desta, encontráveis em quase todos os seus livros. Também escreveu admiravelmente sobre animais, com vários contos dedicados a cães, galos, gatos e bodes; em "Esmeralda" (1907), logrou "ser cavalo por alguns dias", desejo de uma personagem de $O$ Fosso (1909), romance sobre a prostituição e a mais fraca das suas narrativas longas.

Na época de reação política de 1907-13, ele, autor de obras escritas no espírito do humanismo característico da literatura russa, várias das quais colocadas entre as melhores desta, colaborou em jornais e revistas vulgares, que se multiplicaram com rapidez. Malogrou de vez o seu casamento; em 1907, morava já sozinho em um hotel. Por Petersburgo, andavam de boca em boca os versos: "Iésli ístina v vinié, Skolhko ístin v Kuprinié!" ("Se a verdade na vodca está, então, quantas verdades em Kuprin não há?!")... Contraiu segundas núpcias, mas caía, volta e meia, na boêmia e cometia desatinos. Desafiou a duelo um jornalista, que escrevera um pasquim sobre ele; o ofensor 


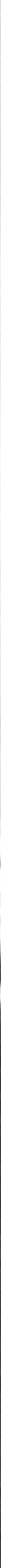

ivis $1020 \mathrm{~s} 4$-IIIIIIII

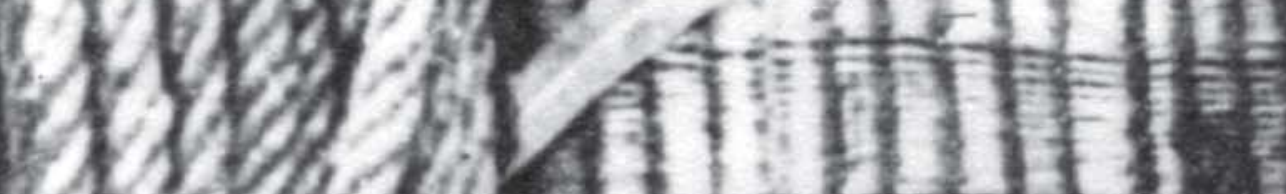
1010 (2) $(1)$

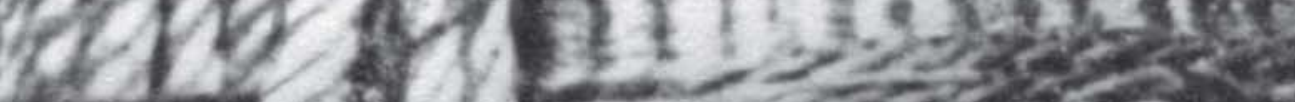

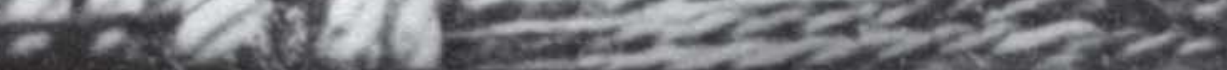


10 Maksim Górki escreve a Konstantin Trenióv, da Itália: "Estou atribulado com essa história [...]. Pego os jornais russos com medo, jornais russos com medo, tos mais triste pena de Aleksandr Ivánovitch e temo muito por ele". V. Afanássiev. A. I. Kuprin. Krítiko-biografítcheski ótcherk (A. I. Kuprin Ótcherk Crítico-biográfico) Moscou, 1960, gráico), Moscou, 1960, Tchukóvski, foi Fiódor Bátiuchkov, professor da Universidade de São Petersburgo e o mais devotado amigo de Kuprin, quem o demoveu da idéia de retaliação.

11 A. Vólkov, Tvórtchestvo A I. Kupriná (A Obra de A. Kuprin), Moscou, 1981, pp. 330-1.

12 A Finlândia, parte do império russo, torna-se país soberano um mês após a Revolução de Outubro.

13 Ksénia Aleksándrovna Kupriná, no seu livro sobre o pai, lembra que, não raramente, para comer, em casa, os três não tinham mais do que dois pepinos mais do que dois pepinos pão.

14 A. Vólkov, op. cit., pp. 337-8.

15 Na descrição das comoções juvenis, ingênuas mas puras, Kuprin ressuscita com psicólogo e poeta; faz, po outro lado, certo encômio às instituições tzaristas.

16 Era a época dos tristemente famosos "processos de Moscou". Sob a acusação de tentar matar Stálin outros dirigentes, tenta destruir o poderio econômico e militar do país e quere restaurar o capitalismo, agentes de nações esrangeiras, estavam a se julgados, e eram, quase sempre, condenados a morte, bolcheviques da veIha guarda (todo o Politburo de Lênin, com exceção de Trótski, já fora da União Soviética), bem como generais, os comandante de todos os distritos militares importantes, quase todos os embaixadores soviéticos na Asia e Europa muitas outras pessoas. pretexto para o inicio dos pretexto para o ini expurgos e do terror d massas foi o assassínio de Serguéi Kírov, chefe do Partido Comunista em Leningrado, ocorrido em 1934, provavelmente com a cumplicidade de Stálin. foragiu-se, e o escândalo aumentou (10)... Apesar de se refletirem em Kuprin os ânimos políticos do meio degenerado ao qual se ligara, não se pode falar em decadência moral sua, pois, além de contos certamente desabonadores dele ("Enjôo", por exemplo), publicou alguns ("Anátema", "O Raio Negro" e outros) que falavam eloqüentemente da intocabilidade da natureza democrática e humanística da sua criação. Ademais, quando sacudia de si os vapores do álcool e ia para algum sítio silvestre, recuperava a lucidez de espírito, o ânimo e a alacridade.

Quando se iniciou a Primeira Guerra Mundial, Kuprin alistou-se como voluntário. Enviaram-no para a Finlândia; ali, instruiu soldados e chegou a comandar uma companhia, mas desmobilizaram-no pouco depois, por causa da saúde abalada pelo tifo. Voltou para Gátchina, cidadezinha próxima de Petersburgo.

A Revolução Socialista de 1917 representou verdadeiro divisor de águas na vida de Kuprin. A convite de Maksim Górki, trabalhou na editora Literatura Universal (escreveu extenso prefácio à coleção das obras de Alexandre Dumas-pai, de quem gostava muito, e traduziu a tragédia Dom Carlos, de F. Schiller), manifestou, em artigos de jornal, simpatia e respeito aos bolcheviques e encontrou-se com Lênin, no Krêmlin, para obter autorização para a fundação de um jornal camponês. No entanto, se, no conto “A Lagarta”, louvara os revolucionários de 1905, em “O Fantasma de Gátchina" (1919), demonstrou incompreensão dos novos tempos.

"Kuprin não conseguiu, apesar de tudo, superar a barreira que separa a mundividência e a psicologia do democrata do ensinamento revolucionário, que subleva o povo. Os planos dos bolcheviques para a reorganização social do país pareciam-lhe utópicos. [...] Kuprin não conseguiu orientar-se na situação política. Mas não se pode culpá-lo por isso. Grassava a fome, a destruição parecia não ter fim, havia a guerra civil, e quase todos os seus amigos e conhecidos estavam do lado dos inimigos da revolução. No fogo da revolução e da guerra civil, nas trevas da fome e da destruição, erros foram cometidos até por pessoas de convicções mais firmes e de visão clara do mundo (Górki, por exemplo)" (11).

No outono de 1919, regimentos brancos derrotados passaram por Gátchina, e Kuprin, com a segunda esposa e a filha, seguiu com eles para a Finlândia (12). Dali, partiu para a França.

Como ele, emigraram Alekséi Tolstói, Ivan Búnin, Leonid Andréev, Dmítri Merejkóvski, Boris Záitsev e outros literatos, o compositor Serguéi Rakhmáninov e artistas.

Kuprin trabalhou em publicações antisoviéticas, provou grandes dificuldades materiais (13) e logo se convenceu de estar em meio pernicioso a ele, como pessoa e artista: "Viver no exílio, ainda mais entre russos, e, ainda mais, russos de segunda convocação, é o mesmo que viver em um cômodo pequeno, em que quebraram uma dúzia de ovos podres" (14).

O romance Os Cadetes (1932), sua única obra significante desse período, cristalizou as lembranças do passado, a saudade da Rússia (15). Kuprin sentiu-se sempre estranho ao ambiente francês e deixou de escrever muito antes da morte. Do homem que esbanjava saúde na pátria restava apenas um velho magro e doente, disposto a voltar para casa nem que fosse a pé.

O governo soviético permitiu o seu regresso. Em 31 de maio de 1937, Aleksandr Ivánovitch chegou de trem a Moscou e teve recepção calorosa. Vivia-se o auge do clima de terror instaurado por Ióssif Stálin (16), e Kuprin certamente horrorizou-se com isso e outras coisas.

Operários e soldados convidavam-no às suas festas, pessoas cumprimentavam-no na rua, saíam edições das suas obras, e o carinho com que o cercaram devolveu-lhe um pouco da saúde, enchendo-o de planos. Conseguiu, porém, escrever apenas uns poucos "Fragmentos de Recordações" e o artigo "Moscou Querida".

Kuprin faleceu em 25 de agosto do ano seguinte, de câncer do esôfago, e o seu corpo baixou à sepultura no cemitério de Vólkovo, em Leningrado. A esposa, Elizaveta 
Morítsovna Kupriná (17), morreu durante o bloqueio alemão da cidade, na Segunda Guerra Mundial, e a filha, Ksénia Aleksándrovna Kupriná, que chegou a trabalhar em cinema na França, retornou à União Soviética em 1958.

\section{•・}

Kuprin, criador de imagens elevadas, tendia a uma linguagem patética e comovida e, por outro lado, descobria grande afeição a todas as coisas mundanas. No início da sua carreira literária, a crítica falava já da corporeidade e da tangibilidade das suas figuras, do seu "sensualismo". Uma mirada jubilosa para o mundo e a poesia das impressões representavam uma constante na sua obra.

Esta encerra a compreensão e o sentimento dos gozos terrenos, e, qual delicado objeto de vidro, esfriou-se com um sopro de bondade, moldada por mãos que se compraziam tanto com o frio do barro quanto com a calidez do pão. O seu estilo revela uma pessoa cuja alma se alvoroçava aos estímulos mais básicos - fosse o pio aveludado de uma ave ou o ribombar do trovão. A natureza do homem materializou-se nas criações do escritor, e isso nutriu o realismo lírico de Kuprin; ele apresentava a realidade em todo o seu aspecto desgracioso e até sórdido, mas não permitia que ela se reduzisse a algo mesquinho e baço; por outras palavras, retratava a vida com a poesia inerente a ela, isto é, o perfume dos bens passados, o sorriso da quimera, o afago da ternura, a luz imprevista, que, ao incidir sobre uma coisa, comunica a esta um halo de pureza e transcendência.

A sua prosa lembra as fotografias na primeira prova, desprovidas do retoque muitas vezes desfigurador, sem artifícios, e, por isso justamente, reais nas partes belas e nas feias. Kuprin meteu-se na voragem da existência, buscando as suas leis mais fundamentais, e fez um canto às coisas boas, sem fechar os olhos às torpezas que as rodeavam. Sabia transmitir imperiosamente sensações vívidas e diretas, com assombrosa capacidade de perceber a vida e criar cenas vibrantes, cheias de intenso e poético sentimento. Segundo ele, as pessoas não nascem simplesmente para morrer, mas para trazer algo novo, seu, à beleza do mundo, e disseminar a percepção dessa maravilha constitui uma das missões do artista. Assim, esmerava-se na descrição das circunstâncias em que as personagens provavam um alento vigoroso da sua ligação à terra. Tais cenas trazem uma exortação ao leitor a que apure os sentidos para a captação do íntimo segredo da vida e se descubra a si e a todo ser vivente - portador do princípio de harmonia e amor do Universo.

"O menino deu acordo de si somente ao chegar à fonte, ao pé da qual ele e o avô desjejuaram na véspera. Atirando-se juntos de boca à nascente fria, o cão e o homem sorveram longa e avidamente a água fresca, gostosa. Eles se empurravam e de quando em quando levantavam a cabeça para tomarem alento; a água, então, pingava sonora dos seus lábios, e os dois deixavam-se outra vez cair sobre a nascente com nova sede, incapazes de desprender-se dela. Quando eles finalmente se apartaram dela e seguiram adiante, nos seus estômagos repletos marulhava e grugulejava a água. Passara o perigo, desapareceram sem vestígios todos os terrores daquela noite, e ambos sentiam a alegria e doçura de ir pelo caminho branco, iluminado pela Lua, por entre moitas escuras, das quais emanavam já a umidade da manhã e o suave aroma das folhas refrescadas",assim Kuprin conclui o conto "O Cão de Águas Branco".

O poder de comoção desse e de tantos outros registros perfeitos e cheios de sensibilidade de um estado de felicidade completa provém da vitalidade de corpo e espírito de Kuprin, da grande força estuante, que o fazia expandir-se em solicitude com todos os viventes do mundo e rejubilar-se de respirar sob o céu e decaminhar sobre o chão. O entusiasmo em face da menor manifestação do encanto do próprio fato da nossa existência e a glorificação dos impulsos naturais e saudáveis do homem representaram os principais auxiliares desse russo admirável, que deixou uma obra radiante, manancial de alegria e inspiração para todos nós (*).
17 Em 1907, Elizaveta Morítsovna, então de sobrenome Pótoni, trabalhava em um hospital e ali cuidou de Lídia Kupriná, filha do escritor. A esposa deste, vendo o apego das duas, pediu-lhe que ficasse com menina até a cura definpediu-he que ficasse com ava, na herdade do já citado Fiódor Bátiuchkov. Aleksandr Ivánovitch apaixonou-se por ela e declarou o seu amor. Elizaveta Morítsovna, apesar de retribuir-Ihe o sentimento, coparecen como porto. canto. Ele, logo depois, deixou a família e entregouse de vez a uma vida de senfreada, bebendo muito. Fiódor Bátiuchkov procurou a moça incansavelmente, até encontrá-la emum pital distante; completapital distante; completamente afastada da realidade, dedicava-se de alma inteira aos internos de uma ala de doenças contagiosas. Salvar pessoas constituía a sua vocação natural, ela fizeraisso naguerral, eela fizeraisso naguerra russo-japonesa (19045) comoirmã de caridade. Fiódor Bátiuchkov valeu-se justamente disso como argumento, implorando-lhe que fosse com ele, e conseguiu convencê-la de que Kuprin havia muito não Keliz no casamito ná era deceria a ela inteiramente. Elizaveta Morítsovna impediu que a vida do escritor terminasse de maneira estúpida e violenta. Nela, encontrou Kuprin a pureza verdadeira a bondade copde Kuprin a pureza cepcional, de cuja proxim dade precisava não somente para criar, senão também para continuar a viver.

* Os três contos a seguir têm tradução e notas de Noé Silva. 


\section{DEMIR-KAIA LENDA ORIENTAL}

$\mathrm{O}$ vento amainou. Hoje, talvez tenhamos de passar a noite no mar. Trinta verstas separam-nos da praia. A faluca, de dois mastros, balouça-se preguiçosamente, de uma borda à outra. As velas pendem, molhadas.

Denso nevoeiro branco envolveu o barco. Não se vêem as estrelas, o mar ou a noite. Não acendemos nenhuma luz.

Seid-Abili, o velho, imundo e descalço capitão, conta, em voz baixa, séria e profunda, uma história, na qual eu acredito de todo o coração. Acredito, porque a noite está tão estranhamente quieta, porque, sob nós, dorme o mar invisível, e nós, envoltos pela cerração, navegamos lentamente, em nuvens brancas e espessas.

Era uma vez certo Demir-Kaia. Na vossa língua, significa "Penhasco de Aço". Chamavam-lhe assim porque não conhecia a piedade, a vergonha ou o medo. Exercia rapinagens, com o seu bando, nos arredores de Istambul, na Tessália abençoada, na Macedônia montanhosa e nas pastagens férteis da Bulgária. Noventa e nove pessoas tiveram a morte pelas suas mãos; entre elas, mulheres, velhos e crianças.

Certa feita, porém, uma hoste forte do padixá - Alá prolongue os seus dias! - cercou-o nas montanhas. Demir-Kaia resistiu três dias, defendendo-se qual lobo de uma matilha de cães. Na manhã do quarto dia, rompeu o cerco, mas estava sozinho. Parte dos seus companheiros morrera durante a perseguição encarniçada; os restantes foram executados pelo carrasco em Istambul, na praça circular.

A esvair-se em sangue, dos muitos ferimentos, jazia ele ao pé de uma fogueira, em uma caverna inexpugnável, em que o recolheram pastores selvagens dos montes. No meio da noite, apareceu-lhe um anjo luminoso, com uma espada incandescente. Demir-Kaia reconheceu Asrail, mensageiro da Morte e enviado do Céu.

- Seja feita a vontade de Alá! Eu estou pronto.

$\mathrm{O}$ anjo, porém, disse:
- Não, Demir-Kaia, a tua hora não chegou ainda. Escuta a vontade do Senhor. Quando te levantares do leito da Morte, parte, desenterra os teus tesouros e transformaos em ouro. Caminharás, depois, sempre para o nascente, até a um sítio, onde sete caminhos se cruzam. Construirás, ali, uma casa de aposentos bem arejados, com divãs largos, água de fontes para as abluções, comidas e bebidas para os viajores, café aromático e narguilé olente para os fadigados. Convida a entrar todos que passarem em frente à tua morada, e serve-lhes como o mais humilde dos escravos. Seja, o teu lar, a sua casa; o teu ouro, a sua riqueza; o teu trabalho, o seu repouso. Chegará um dia, em que Alá olvidará os teus graves pecados e te perdoará o sangue dos filhos seus.

Demir-Kaia, porém, perguntou:

- Que sinal me dará o Senhor da remissão dos meus pecados?

Respondeu-lhe Asrail:

- Dessa fogueira, que arde já lentamente, pega um tição coberto de cinza e plantao. Quando a madeira morta vestir casca, deitar brotos e florescer, então saberás: é chegada a tua redenção.

Passaram-se vinte anos. Por todo o país do padixá - Alá prolongue os seus dias! correu a fama de um caravançará próximo àquela encruzilhada, na estrada de Jeddáh a Esmirna. O mendigo saía dali com rúpias no farnel; o faminto, saciado; o cansado, bem disposto; o ferido, curado.

Durante vinte, vinte longos anos, todas as noites, Demir-Kaia olhou o pedaço de madeira, que fincara no chão do pátio, mas aquele permaneceu sem vida. Os seus olhos perderam o brilho, o corpo vigoroso encurvou-se, e os cabelos ficaram brancos como as asas de um anjo.

Certa madrugada, ao ouvir um tropel, saiu correndo à estrada; em um cavalo coberto de espuma, passava um homem a galope. Demir-Kaia arrojou-se para ele, segurou o animal pela cabeçada e implorou ao estranho:

— Ó irmão, vem a minha casa. Refrigera o rosto com água, come e bebe para te refocilares, delicia os lábios com o doce aroma do narguilé. 
O viajor, porém, gritou-lhe com raiva:

- Deixa-me, velho! Deixa-me!

Cuspiu no rosto de Demir-Kaia e golpeou-lhe a cabeça com o cabo do açoite, prosseguindo a carreira.

O sangue altivo de bandoleiro ferveu em Demir-Kaia. Ele levantou pesada pedra do chão, arremessou-a no ofensor e partiu-lhe o crânio. O cavaleiro balançou sobre a sela, levou as mãos à cabeça e caiu sobre o pó do caminho.

Demir-Kaia precipitou-se para ele, com o coração aflito, e disse, consternado:

— Irmão, eu te matei!

Respondeu-lhe, porém, o moribundo:

— Não foste tu, mas a mão de Alá. Escuta. O paxá do nosso vilaiet (1) é um homem cruel, cúpido, injusto. Amigos meus tramaram conspiração contra ele. Mas eu me deixei seduzir por grande prêmio em dinheiro. Eu queria delatá-los. Eis que, quando me apressava com a denúncia, fui detido pela pedra, que atiraste. Assim quer Alá. Adeus...

Ralado pela dor, tornou Demir-Kaia à casa. A escada da virtude e do arrependimento, pela qual se alçara durante vinte anos inteiros, quebrara-se na base e ruíra em um único instante de uma manhã estival.

Em desespero, olhou para o sítio, onde a sua mirada soía deter-se no tição carbonizado. De repente, um milagre ante os seus olhos! Vê a madeira morta deitar renovos, cobrir-se de brotos, vestir-se de verdor perfumado e ornar-se de meigas flores amarelas.

Prostrou-se e pôs-se a chorar de alegria. Porquanto sabia que o grande e todo-misericordioso Alá, na sua inefável sabedoria, lhe perdoara, pela morte de um traidor, as noventa e nove vidas, que lhe pesavam na consciência. [1906]

\section{A FELICIDADE}

Um grande imperador ordenou que lhe apresentassem todos os poetas e sábios do seu país. Perguntou-lhes:

— Em que está a felicidade?

- Em ver sempre - apressou-se a responder o primeiro - o resplendor do teu rosto divino e sentir eternamente...
- Furai-lhe os olhos - disse o imperador, com indiferença. - O seguinte!

- A felicidade é o poder. Tu, imperador, és feliz! - gritou o segundo.

O imperador retrucou-lhe com um sorriso amargo:

- Porém eu sofro de hemorróidas e não tenho o poder de curá-las. Arrancai as ventas a esse canalha! Prossigamos!

— Ser rico! - disse o seguinte, a gaguejar.

O monarca respondeu:

- Eu sou rico mas fiz uma pergunta sobre a felicidade. Bastar-te-ia uma barra de ouro do peso da tua cabeça?

- Oh, Majestade!

— Tu a receberás. Atai-lhe ao pescoço uma barra de ouro do peso da sua cabeça e lançai este mendigo ao mar.

Em seguida, gritou com impaciência:

- O quarto!

Acercou-se, a rastejar, um homem esfarrapado, de olhos febris, e balbuciou:

- Oh, sapientíssimo! Eu quero pouco! Eu estou faminto! Dá-me comida, e eu glorificarei o teu nome no mundo inteiro.

- Alimentai-o - disse o soberano, com asco. - Quando ele morrer de tanto comer, vinde dizer-mo.

Aproximaram-se mais dois. Um, vigoroso atleta de corpo rosado e fronte baixa, disse, com um suspiro:

- A felicidade está na Arte.

O outro era um poeta magro e pálido, em cujas faces ardiam manchas vermelhas. Disse:

— A felicidade está na saúde.

$\mathrm{O}$ imperador sorriu com amargura.

- Se estivesse em meu poder mudar os vossos destinos, então, daqui a um mês, tu, poeta, implorarias inspiração aos deuses, ao passo que tu, Hércules, correrias aos médicos a pedir pílulas atrofiantes. Ide ambos em paz. Quem mais há lá?

- Imortal! - disse, orgulhosamente o sétimo, ornado com as cores de Narciso. - A felicidade está no não ser.

- Cortai-lhe a cabeça! - proferiu o soberano, com preguiça.

— Majestade, ó Majestade, clemência! ...-pôs-se a balbuciar o condenado, e empa1 Vilaiet: unidade da divisão
territorial e administrativa
da Turquia. 
lideceu mais do que as pétalas de um narciso. - Eu não quis dizer isso.

Mas o imperador fez um movimento com a mão, de cansaço, bocejou e ordenou sumariamente:

— Levai-o... Cortai-lhe a cabeça. A palavra do imperador é firme como a ágata.

Abeiraram-se ainda muitos outros. Um disse apenas três palavras:

- $\mathrm{O}$ amor feminino!...

- Muito bem - concordou o monarca dai-lhe uma centena das mulheres mais belas do meu país. Mas dai-lhe, também, uma taça de veneno. Quando chegar a hora, dizeimo: eu irei olhar o seu cadáver.

Um outro disse:

- A felicidade está em que cada desejo meu se realize instantaneamente.

- Que queres neste momento? - perguntou-lhe o imperador, maliciosamente.

- Eu?

- Sim. Tu.

— Majestade... a pergunta foi inesperada demais.

—Enterrai-o vivo. Ah, então temos mais um sábio? Ora, ora. Achega-te... Não saberias em que está a felicidade?

O sábio - e ele era um verdadeiro sábio - respondeu:

— A felicidade está no esplendor do pensamento humano.

O soberano teve um estremecimento de sobrancelhas e entrou a gritar, colérico:

- Ah-ah! O pensamento humano! Que é o pensamento humano?

O sábio - pois ele era um verdadeiro sábio - apenas sorriu, compadecido.

Então, o imperador ordenou que o atirassem à masmorra, onde havia escuridão eterna e não penetrava nenhum som de fora. Um ano depois, conduziram a ele o cativo, que ficara cego e surdo e mal se agüentava em pé.

— Então? Ainda agora és feliz?

O sábio respondeu tranqüilamente:

- Sim, sou feliz. Na prisão, fui imperador, dono de tesouros, amei, tive mesa farta, passei fome, e tudo isso me foi dado pelo meu pensamento.

— Mas que é o pensamento?! - exclamou o monarca com impaciência. - Pois sabe que, daqui a cinco minutos, eu te enforcarei e cuspirei no teu rosto maldito! Então, ainda te consolará o teu pensamento? Onde estarão, então, os pensamentos, que desperdiçaste pelo mundo?

O sábio respondeu-lhe tranqüilamente, pois era um verdadeiro sábio:

- Parvo! O pensamento é imortal.

\section{NO CIRCO}

I

O doutor Lukhovítski, que se considerava o médico permanente do circo, mandou Arbúzov tirar a camisa. Apesar da corcunda, e talvez até por esse defeito, votava, aos espetáculos circenses, um amor pungente e um tanto ridículo em uma pessoa da sua idade. É bem verdade que recorriam aos seus préstimos mui raramente, porque, naquele mundo, se tratam contusões, reanimam pessoas e reduzem luxações por meios próprios, invariavelmente transmitidos de geração a geração, provavelmente desde os tempos dos primeiros Jogos Olímpicos. Isso, no entanto, não o impedia de assistir a todas as funções vespertinas, conhecer de perto todos os cavaleiros, acrobatas e malabaristas afamados e de usar palavrinhas do léxico da arena e da estrebaria.

Dentre todas as pessoas ligadas ao circo, os lutadores profissionais e os atletas suscitavam-lhe uma admiração especial, que beirava com a verdadeira paixão. Por isso, quando Arbúzov tirou a camisa engomada e a camisola de tricô, usada por todos os circenses, sem exceção, e ficou de peito nu, o pequeno doutor até esfregou as mãos de satisfação, volteando em torno daquele, a admirar-lhe o corpanzil bem cuidado, brilhante e rosado, de músculos bem salientes e duros como madeira.

- O Diabo o carregue, que baita força! - dizia, a apertar ora um ombro do atleta, ora o outro, com os dedos finos e tenazes. - Isso não é já nem de gente, mas de um cavalo, com a breca. Com o seu corpo, é possível dar aula de Anatomia sem usar atlas. Vamos lá, amigo, dobre o braço.

Arbúzov suspirou e, após sonolento olhar 
de esguelha para o braço esquerdo, dobrou$\mathrm{o}$; inflando a fina pele acima do cotovelo e esticando-a, cresceu e rolou, em direção ao ombro, uma esfera grande e rija, do tamanho da cabeça de uma criança. Simultaneamente ao toque dos dedos frios do médico, a parte desnuda do seu corpo recobriu-se de erupções minúsculas e ásperas.

- Pois, meu caro - continuou Lukhovítski, entusiasmado-, Deus realmente quis favorecê-lo. Vê essas pelotas aqui? $\mathrm{Na}$ nossa Anatomia, chamam-se bíceps, ou seja, bicéfalos. E esses são os chamados supinadores e pronadores. Gire o punho, como se uma chave para abrir uma porta. Isso, isso, excelente. Vê como se movem? E esses, que tateio no ombro, são os músculos deltóides. Sente? Os seus são como dragonas de coronel. Ah, mas que sujeito forte você é! Que seria da pessoa, a quem você assim... involuntariamente? Hem? Ou, então, que desse de cara com você em um sítio escuro? Hem? Barbaridade, Deus o livre! Eh-eh-eh! Pois, então, quer dizer que nos queixamos de sono ruim e de fraqueza geral?

Arbúzov sorria o tempo todo, tímida e indulgentemente. $\mathrm{Na}$ presença do franzino médico, sentiu embaraço, quase vergonha do seu corpanzil musculoso e forte, embora há muito já se houvesse acostumado a ficar seminu ante pessoas vestidas.

- Temo que me constipei, doutor - disse com voz aguda, débil e um tanto roufenha, totalmente destoante da sua figura maciça. Principalmente porque os camarins são uma pouca vergonha, as paredes estão cheias de frestas. Durante o número, como sabe, ficamos suados, e, depois, temos de mudar de roupa no meio de correntes de ar, que entram de todos os lados. E aí se apanha um resfriado.

- Dói a cabeça? Tem tossido?

- Não, tossir, eu não tusso, mas a cabeça...-Arbúzov esfregou a nuca com a palma da mão. - A cabeça, a bem dizer, alguma coisa está errada nela. Não dói, é só... como se houvesse um peso em cima... E também durmo mal. Principalmente no começo. Saiba, assim: estou quase já para adormeceradormecer, e, de repente, como que uma coisa me atira para cima; como se eu tivesse levado um susto. Até o coração bate mais forte. Isso três ou quatro vezes, e eu acordo sempre. De manhã, a cabeça e, de modo geral... sinto-me lá um tanto azedo.

- Põe sangue pelo nariz?

- Acontece às vezes, doutor.

- Po-ois. É-é... - arrastou Lukhovítski, significativamente, e arqueou os sobrolhos, baixando-os em seguida. - Quem sabe não se tem exercitado muito, ultimamente? Não se sente cansado?

- Muito. Agora, é máslenitsa (2), e temse de trabalhar com pesos todos os dias e, de quando em quando, até duas vezes por dia, por causa das apresentações matinais. E, dia sim, dia não, eu luto, além de fazer o número habitual... Claro, fica-se muito cansado...

- Pois, pois, pois - fazia-lhe coro o doutor, aspirando o ar e sacudindo a cabeça. Pois bem, agora, nós o auscultaremos. Abra os braços. Ótimo. Respire agora. Calmamente, calmamente. Respire... mais fundo... mais regularmente...

O pequeno médico, que mal chegava, em altura, ao peito do lutador, aplicou sobre esse o estetoscópio e iniciou a auscultação. A olhar assustado para a sua nuca, Arbúzov inspirava ruidosamente e expirava o ar com os lábios arredondados, para não lhe soprar sobre a risca brilhante dos cabelos.

Depois de auscultá-lo e percuti-lo, Lukhovítski sentou-se sobre um canto da mesa, cruzou as pernas e abraçou os joelhos, pontudos. O seu rosto de pássaro, saliente para a frente, largo nos zigomas e afilado no queixo, tornou-se sério, quase severo. Refletiu um momento e disse, a olhar para uma estante de livros:

- Não lhe encontro nada de grave, meu amigo, embora essa arritmia cardíaca e a hemorragia pelo nariz bem possam considerar-se advertências delicadas lá do outro mundo. Compreenda, você tem tendência à hipertrofia do coração. Ela é, por assim dizer, uma doença, a que está sujeito quem faz esforço físico intenso: ferreiros, marinheiros, ginastas e assim por diante. Por causa do esforço constante e excessivo, as paredes do coração alargam-se, e daí vem o que, em Medicina, se chama cor bovinum, ou seja, coração de boi. Um belo dia, esse coração
2 Máslenitsa: feriado tradicional russo, que corresponde, aproximadamente, ao Carnaval. Inicialmente, relacionava-se com os festejos da entrada da primavera, mas acabou tornando-se feriado oficial da Igreja Ortodoxa. 
recusa-se a trabalhar, fica paralisado, e, aí então, basta, acabou o espetáculo. Não se preocupe, está ainda muito longe de tão desagradável momento, mas, em todo caso, eu aconselho: nada de café, chá forte, bebidas alcoólicas e demais coisas estimulantes. Compreende? - perguntou Lukhovítski, a tamborilar com os dedos na mesa e a olhar de soslaio para Arbúzov.

- Compreendo, doutor.

- Recomenda-se a mesma moderação também em todo o resto. Certamente compreende do que falo, não?

$\mathrm{O}$ atleta, que abotoava os punhos e o colarinho da camisa, corou e sorriu, embaraçado.

- Compreendo... mas, como sabe, na nossa profissão, é preciso ser moderado até sem motivo sério. E, a dizer a verdade, nem tenho tempo para pensar nisso.

- Pois, ótimo, meu amigo. Descanse um diazinho, dois e até mais, se puder. Não é hoje a luta com o Roeber? Tente adiá-la. Impossível? Pois, então, diga que está doente, e acabou. Eu o proíbo de lutar, está a ouvirme? Vamos olhar essa língua. Aí está, horrível, também ela. Não se sente fraco? Eh! Fale com franqueza. De qualquer modo, eu não contarei isso a ninguém, então por que diabos tem medo? É justamente para guardarem segredos que padres e médicos cobram pelos seus serviços. Está muito mal, não?

Arbúzov confessou que realmente não se sentia bem. Às vezes, experimentava fraqueza e algo como preguiça, não tinha apetite e, à noite, sentia calafrios. Quem sabe se o doutor receitasse umas gotas?

- Não, meu amigo, ache lá o que quiser, mas lutar, você não pode - disse o médico com decisão, saltando da mesa. - Como sabe, eu não sou novato neste negócio e a todos os lutadores, que tive a oportunidade de conhecer, sempre disse que, antes de qualquer peleja, observassem estas três regras: primeira - dormir bem, na véspera; segunda - ter um almoço saboroso e nutritivo; terceira - ir de estômago vazio para o combate, e, por fim, quarta - que é já psicológica -, não perder a confiança na vitória nem por um minuto. Pergunta-se: como lutará você, se desde a manhã se sente dessa maneira? Perdoe uma pergunta indiscreta... de uma pessoa da casa... não é a vossa disputa uma daquelas? Não é simulada? Isto é, não está já acertado quem derrubará a quem e em que combate?

-Oh, não, doutor, que isso... Faz já tempo que Roeber e eu corremos um atrás do outro pela Europa inteira. Até a caução é verdadeira e não um chamariz. Tanto ele como eu pusemos cem rublos cada um em mãos de terceiros.

- Ainda assim não vejo razão que impeça adiar a luta.

- Pelo contrário, doutor, há razões muito importantes. Julgue o senhor próprio. A nossa disputa é de três combates. Suponhamos: Roeber ganhou a primeira, eu a segunda; a terceira, então, fica como a decisiva. Mas nós conhecemos já tão bem um ao outro, que é possível dizer, sem medo de errar, quem vencerá a terceira luta; assim, se eu não estou seguro das minhas forças, que me impede, então, de ficar doente ou pôr-me a manquejar, etc., e pegar o meu dinheiro de volta? Para que, então, Roeber haveria lutado as duas primeiras vezes? Só por prazer? Precisamente para um caso desses, doutor, foi acordado por nós que quem estivesse doente no dia da luta decisiva, tanto faz, seria considerado vencido e perderia o dinheiro.

- Pois, pois, negócio nojento - disse o doutor e novamente soergueu as sobrancelhas e baixou-as significativamente. - Pois então, meu amigo, ao Diabo com eles, com esses cem rublos, hem?

-Duzentos, doutor-corrigiu Arbúzov. - Por contrato com a direção, eu pago multa de cem rublos se me recuso a trabalhar em dia de apresentação, ainda que por doença.

- Com o Diabo... que sejam duzentos! - zangou-se o médico. - No seu lugar, eu de qualquer modo me recusaria... Ao Diabo o dinheiro, perdido que seja, a saúde vale mais. No final das contas, meu amigo, corre risco de perder a caução do mesmo jeito, lutando contra adversário tão perigoso como esse estadunidense.

Arbúzov sacudiu a cabeça, com confiança em si, e os seus lábios, grandes, abriramse em um sorriso desdenhoso.

— Eh, tolice - soltou ele, com desprezo 
-, Roeber pesa só seis puds (3) e mal bate no meu queixo, em altura. O senhor verá como eu o porei de espáduas no chão em três minutos. Já o haveria derrubado na segunda luta, se ele não me houvesse prensado à cercadura do picadeiro. Propriamente falando, foi canalhice dos jurados levar em consideração aquela luta infame. Até o público protestou.

O médico esboçou um sorriso malicioso, quase imperceptível. Em contacto freqüente com a vida circense, já conhecia bem e há muito aquela autoconfiança inabalável e gabola dos lutadores profissionais, atletas e boxeadores e a sua tendência a atribuir as derrotas a causas acidentais. A despedir-se de Arbúzov, receitou-lhe bromo, que ordenou tomar uma hora antes do combate, e, após um tapinha amigável nas suas largas espáduas, desejou-lhe vitória.

\section{II}

Arbúzov saiu à rua. Era o último dia da semana da máslenitsa, a qual caíra tarde naquele ano. $\mathrm{O}$ frio não cedera ainda, mas, no ar, sentia-se já o cheiro indefinido e sutil da primavera, que lhe excitava alegremente o peito. Sobre a neve batida e imunda, duas filas de trenós e carruagens passavam rápidas, sem rumor e em sentidos contrários, e os gritos dos cocheiros ouviam-se com sonoridade clara e suave. Nos cruzamentos, vendiam-se maçãs de conserva, em tinas novas e brancas, khalvá (4), semelhante à neve da rua na cor, e balões de gás. Estes avistavam-se de longe. Como cachos multicoloridos e brilhantes, erguiam-se e flutuavam sobre a corrente negra e fervilhante dos passantes, que enchiam as calçadas, e havia, nos seus movimentos, ora impetuosos ora indolentes, algo primaveril e da alegria de uma criança.

No consultório do médico, Arbúzov sentira-se quase bom, mas, ao ar livre, novamente o dominaram as penosas sensações da doença. A cabeça parecia grande e vazia, e cada passo repercutia nela com desagradável zunzum. Na boca ressequida, de novo sentiu gosto de queimado e, nos olhos, uma dor cansada, como se dedos os premessem; quando volvia o olhar de uma coisa a outra, então, juntamente com isso, pela neve, pelas casas e pelo céu, moviam-se duas grandes manchas amarelas.

Perto de um cruzamento, saltou-lhe à vista o próprio nome, impresso em letras garrafais, em um poste roliço. Ele se aproximou maquinalmente. Entre cartazes multicoloridos dos divertimentos do feriado, sob o vermelho costumeiro do circo, estava um verde, em separado, e Arbúzov leu-o com indiferença, do começo ao fim, como se dormisse:

\section{CIRCO DE BR. DUVERNUOIS}

Realizar-se-á hoje o terceiro e decisivo combate de luta romana entre o conhecido campeão estadunidense, Sr. John Roeber,

e o famoso lutador e hércules russo, Sr. Arbúzov, por um prêmio de 100 rublos. Mais pormenores nos cartazes.

Junto ao poste, detiveram-se dois artífices, que, pelos rostos sujos de fuligem, deviam ser serralheiros, e um deles pôs-se a ler o anúncio da luta em voz alta, estropiando as palavras. Arbúzov ouviu o seu sobrenome, e este pareceu-lhe um som pálido, esfarrapado, estranho e desprovido de sentido, como sói acontecer quando repetimos uma palavra durante longo tempo. Os operários reconheceram-no. Um tocou o companheiro com o cotovelo e apartou-se respeitosamente. $\mathrm{O}$ lutador virou-se zangado, enfiou as mãos nos bolsos do casaco e seguiu adiante.

Terminara já a função matinal. A luz penetrava na arena apenas através de uma janela da cúpula, cujo vidro estava coberto de neve, e o circo, na penumbra, parecia um galpão imenso, vazio e frio.

Entrando da rua, Arbúzov distinguiu com dificuldade as cadeiras da primeira fila, o veludo na cercadura do picadeiro e, nos cabos de isolamento das passagens, a douradura dos cantos dos camarotes e os mastros brancos, a que estavam pregados escudos com representações de caras de cavalo e de máscaras de palhaço, além de monogramas. O anfiteatro e a galeria imergiam na escuridão.
3 Pud: medida russa antiga, equivalente a $16,3 \mathrm{~kg}$.

4 Khalvá: doce oriental, feito de nozes, açúcar e óleo. 
No alto, sob a cúpula, via-se o brilho frio do aço e do níquel dos aparelhos de ginástica, presos por roldanas: escadas, argolas, barras fixas e trapézios.

$\mathrm{Na}$ arena, cosidas ao chão, debatiam-se duas pessoas. Arbúzov deixou-se ficar a observá-las largo tempo, apertando os olhos, até que reconheceu o seu adversário, o qual, como sempre de manhã, treinava com um ajudante, também estadunidense, de nome Harvan. No jargão dos atletas profissionais, tais assistentes chamam-se "lobos" ou "cachorrinhos". Viajando por todos os países e cidades com um lutador famoso, auxiliamno no treinamento diário, cuidam do seu guarda-roupa, se a esposa não o acompanha, esfregam-lhe os músculos com luvas ásperas após o banho matinal e a ducha fria e, em geral, prestam-lhe uma porção de pequenos serviços, relacionados diretamente com a profissão. Porquanto os "lobos" são ou atletas jovens e inseguros de si, que não dominaram ainda os muitos segredos do desporto nem desenvolveram uma técnica, ou lutadores velhos mas medianos, raramente conseguem vitória em combates por prêmio. Porém, antes de enfrentar um adversário respeitável, o mestre solta os seus "cachorrinhos" sobre ele, para, acompanhando as lutas, descobrir os pontos fracos e as falhas habituais do futuro rival e avaliar as qualidades, com que deve tomar cuidado. Roeber soltara já sobre Arbúzov um dos seus auxiliares, o inglês Simpson, lutador de segunda categoria, obeso e pesadão, mas conhecido, no meio, pela força do grifo, isto é, da mão e dos dedos. A luta não envolvia prêmio, a pedido da direção do circo, e Arbúzov derrubou o inglês duas vezes, quase a brincar, com dois golpes raros e espetaculares, que não ousaria empregar em luta com algum adversário minimamente perigoso. Já então Roeber assinalara para si os principais defeitos e qualidades de Arbúzov: peso imenso e estatura elevada, a par da força terrível dos braços e pernas, ousadia e determinação nos golpes e também a beleza plástica dos movimentos, que sempre conquistava a simpatia do público, mas, ao mesmo tempo, mãos e pescoço comparativamente fracos, respiração curta e impetuosidade. Ainda então decidira que, contra tal adversário, precisava manter-se na defensiva, enfraquecendo-o e cansando-o; não podia deixar-se agarrar pela frente ou por trás, pois teria dificuldade em defender-se, e, principalmente, devia agüentar as suas primeiras arremetidas, em que aquele selvagem russo demonstrava força e energia realmente colossais. Roeber adotou tal tática nos dois primeiros combates, perdendo um e vencendo o outro.

Quando os olhos se acostumaram à penumbra, Arbúzov enxergou distintamente os dois atletas. Trajavam camisolas cinzentas, que deixavam nus os braços, cintos largos de couro e meias-calças presas nos tornozelos por correias. Roeber encontrava-se em uma das posições mais difíceis e importantes de um atleta em combate, a chamada "ponte". Só com a nuca e os calcanhares encostados no chão, com a espinha arqueada pronunciadamente e o equilíbrio mantido pelas mãos, que se afundavam na areia misturada com serragem, ele representava, com o seu corpo, um arco rijo e vivo; Harvan, pondo todo o seu peso sobre a barriga proeminente e o peito do mestre, empregava todas as forças para endireitar aquela massa de músculos, derrubá-la e apertá-la ao chão.

A cada tranco seu, ambos gemiam, tensos, e tomavam fôlego com dificuldade, em grandes sorvos. À meia-luz incerta, difundida pelo circo deserto, os dois, enormes, pesados, com os músculos terríveis e salientes dos braços nus, e como que hirtos em posturas extravagantes no chão do picadeiro, pareciam caranguejos monstruosos, que se houvessem agarrado pelas pinças.

Pela ética peculiar existente entre os atletas, a qual condena observar os treinos do adversário, Arbúzov, contornando a cercadura do picadeiro e fingindo não ver os contendores, alcançou a saída, que levava aos camarins. Quando ele afastava a pesada cortina vermelha, alguém fez a mesma coisa do lado oposto, e, a sua frente, sob uma cartola brilhante e tombada de banda, surgiram os bigodes negros e os olhos sorridentes e também negros de um grande amigo seu, o acrobata Antonio Batista.

- Buon giorno, mon cher monsieur Arbousoff! (5) - exclamou o italiano, como 
se cantasse, a mostrar os belos e brilhantes dentes, com os braços bem abertos, como se desejasse apertar o lutador neles. - Eu terminei o meu répétition (6) nesse instante. Allons donc prendre quelque chose. Vamos tomar alguma coisa? Um cálice de conhaque? O-oh, só não me quebres a mão. Vamos na cantina (7).

No circo, do diretor aos cavalariços, todos gostavam de Antonio. Era um artista excepcional e versátil: igualmente bem fazia malabarismos, exercitava-se no trapézio e nas barras fixas, adestrava cavalos, encenava pantomimas e, principalmente, tinha uma capacidade inexaurível de inventar novos números, coisa extremamente valorizada no mundo circense, em que a arte, pelas próprias características, quase não evolui e permanece até hoje quase da mesma forma de que era no tempo dos imperadores romanos.

Tudo, nele, agradava a Arbúzov: o temperamento alegre, a generosidade, a delicadeza refinada, notável até entre os artistas de circo, que, fora do picadeiro, onde, por tradição, se admite certa dureza no trato, normalmente se distinguem por uma cortesia cavalheiresca. Apesar da juventude, Antonio lograra já percorrer todas as cidades grandes da Europa e era o companheiro mais desejado e popular em todos os grupos circenses. Dominava igualmente mal todas as línguas européias e misturava-as, quando conversava, estropiando as palavras, talvez um tanto de propósito, pois, em cada acrobata, há sempre um pouco de palhaço.

— Não sabe onde está o diretor? - perguntou Arbúzov.

—Il est à la l'écurie. Ele foi na estrobaria, olhou um cavalo doente. Mais allons donc. Vamos um pouquinha. Eu tenho muito contente de ver o senhor. Meu flór? - disse Antonio de repente, em tom interrogativo, rindo da própria pronúncia e enfiando a mão sob o cotovelo de Arbúzov. - Muito brem, saúde para o senhor, samovar, corcheirô acrescentou como uma metralhadora, ao ver que o outro sorria.

$\mathrm{Na}$ cantina, beberam um cálice de conhaque cada um e mastigaram pedacinhos de limão, salpicados de açúcar. Após a bebida, Arbúzov teve, na barriga, primeiro, a sen- sação de frio e, depois, de um calor agradável. Mas imediatamente sentiu tontura, e certa fraqueza sonolenta espalhou-se por todo o seu corpo.

- Oh, sans doute, san dúvida, terá une victoire, uma vitória - disse Antonio, a girar agilmente o bastão entre os dedos da mão esquerda, e os seus dentes brancos, perfeitos e grandes brilharam sob os bigodes negros. É um tão brave homme (8), um lutador tão maravilhoso e forte. Eu conheci lutador notável, ele chamava Karl Abs... sim, Karl Abs. E ele agora já ist gestorben... ele está morreu. Oh, embora ele alemão, ele foi grande professor! Uma vez ele disse: luta francês é um ninhariazinha. E bom lutador, ein guter Kämpfer, deve ter muito, muito pouco: nada mais que um pescoço forte, da jeita bem de búfala, um espinha extremamente duro, da jeita bem de carregador, um braço comprido com múscula firme und ein gewaltiger Griff... Como é isso em Russo? (Antonio cerrou os dedos da mão esquerda e descerrou-os, várias vezes, diante do rosto.) Oh! Dedos muito forte. Et puis (9), também necessário ter pernos muito firme, da jeita bem de monumenta, e, claro, a maior... comoé?... a maior peso no tronca. Se pegar também um coraçon são, les poumons... como é isso em russo?... pulmões, da jeita bem de cavala, depois também pouquinha de sangue fria e pouquinha de coragem, e também pouquinha savoir les rêgles de la lutte, conhecer todas as regras do luta, então, fim das contas, aí estão todos ninhariazinhas que precisa para lutador bom! Ah, ah, ah!

A rir do próprio gracejo, Antonio agarrou Arbúzov carinhosamente pelo casaco, à altura das axilas, e imediatamente ficou sério. No seu belo rosto bronzeado e vivo, havia uma particularidade admirável: logo depois do riso, tomava um aspecto severo e sombrio, quase trágico, e tal mudança de expressão sobrevinha tão rápida e tão inesperadamente, que parecia que Antonio tinha duas faces - uma, sorridente, a outra, séria -, e que trocava uma pela outra conforme a sua vontade, de maneira incompreensível.

- Claro, Roeber é adversário perigoso... Lá, na América, eles lutam comme les bouchers, como açôgueros. Eu vi luta em

\footnotetext{
6 Ensaio (fr.).

7 Os erros, aqui e adiante, são da fala da personagem.

8 Homem valoroso (fr.).

$9 \mathrm{E}$ depois (fr.).
} 
Chicago e em Nova York... Fu, que nojo!

Com a sua rápida gesticulação de italiano, que explicava as palavras, Antonio pôsse a falar dos lutadores estadunidenses, de modo minucioso e interessante. Entre eles, são permitidos todos os golpes cruéis e perigosos, que se proíbe usar em todas as arenas da Europa. Nos Estados Unidos, os lutadores apertam o pescoço um ao outro, tapam a boca e o nariz do adversário, agarrandolhe a cabeça com um truque medonho, a chamada "coleira de ferro" - colier de fer, privam-no da consciência com hábil pressão dos dedos sobre as artérias carótidas. Terríveis golpes secretos, cuja ação nem sempre é clara até para os médicos, passam de professores para discípulos, compondo impenetrável segredo profissional. Conhecendo tais truques, o lutador pode, por exemplo, com uma pancada leve e aparentemente involuntária no tríceps, provocar a paralisia momentânea do braço do adversário ou, com um movimento imperceptível para os outros, causar-lhe dor tão insuportável, que o fará esquecer todos os cuidados. Havia pouco tempo, o próprio Roeber fora levado a tribunal porque, em Lodze, em combate com o famoso lutador polaco Vladislávski, agarrou o braço deste por cima do ombro, no truque tour de bras (10), entortando-o para o lado oposto ao da dobradura natural, apesar dos protestos do público e do próprio adversário, e lhe rompeu os tendões de ligação do ombro ao antebraço. Os estadunidenses não têm nenhum brio artístico e lutam tendo em mente apenas o dinheiro do prêmio. O seu objetivo maior é amealhar uns cinqüenta mil dólares, encher-se de banha logo em seguida, degenerar-se e abrir um botequim em algum canto de São Francisco, no qual, às escondidas da polícia, prosperem as variedades mais cruéis do boxe daquele país.

Tudo isso, inclusive o escândalo de Lodze, era já de muito do conhecimento de Arbúzov, e o que mais o entretinha não eram os fatos narrados por Antonio, mas as suas próprias, estranhas e doentias sensações, para que ele atentava com espanto. Às vezes, parecia-lhe que o rosto de Antonio quase se encostava ao seu, e cada palavra soava tão alta e áspera, que até repercutia como um zunzum angustiante na sua cabeça, mas, um minuto após, o amigo começava a afastarse, para cada vez mais longe, até o seu rosto tornar-se opaco e ridiculamente pequeno; a sua voz, então, soava baixa e abafada, como se falasse a Arbúzov por telefone ou de um aposento distante. O mais admirável de tudo era que a mudança de tais impressões dependia do próprio Arbúzov e ocorria conforme ele se entregava à agradável e sonolenta languidez, que o dominava, ou, fazendo um esforço, a sacudia de si.

- Oh, eu não tenho dúvida, vós ides derrubar Roeber, mon cher Arbouzoff, meu caridinho, meu cairo - disse Antonio, a rir e a estropiar as palavras carinhosas russas. Roeber c'est un animal, un accapareur (11). Ele profissional sem espírito criador, como aguadeiro, sapateiro, um... un tailleur, o que fazer roupa. Ele não tem nada aqui... dans le coeur... no coraçon, nenhuma sentimento e nenhum temperament. Ele grande açôuguero rude, e vós verdadeiro artista... Vós artista, e eu tenho sempre prazer olhar para vós.

$\mathrm{Na}$ cantina entrou, a passos rápidos, o diretor do circo, homem pequeno, gordo, de pernas finas e ombros levantados, sem pescoço, de cartola e casaco de peles aberto, muito parecido ao retrato de Bismarck, pelo rosto redondo de buldogue, bastos bigodes e a expressão dura das sobrancelhas e dos olhos. Arbúzov e Antonio levaram ligeiramente a mão ao chapéu. Ele lhes retribuiu o cumprimento e imediatamente, como alguém que se houvesse contido muito tempo e apenas esperasse uma ocasião, largou a xingar um cavalariço, que o enfurecera.

- Mujique, canalha russo... deu de beber a um cavalo suado, com os diabos!... Eu irei ao juiz de paz, e ele sentenciará esse patife a pagar-me uma multa de trezentos rublos. Eu... com os diabos!.. Eu irei lá e vou quebrar-lhe a fuça, eu vou açoitá-lo com o meu Reitpeitsch! (12).

Exatamente como se ele se houvesse agarrado a tal pensamento, virou-se rapidamente e, corricando com as pernas finas e ágeis, foi em direção à estrebaria. Arbúzov alcançou-o junto à porta.

- Senhor diretor... 
Este deteve-se abruptamente e, com o mesmo rosto descontente, enfiou as mãos nos bolsos da peliça, em atitude de expectativa.

Arbúzov pôs-se a pedir-lhe que adiasse a luta daquela noite por um dia ou dois. Se desejasse, ele, Arbúzov, daria, em troca, duas ou até três apresentações vespertinas com halteres, fora das condições acordadas entre eles. Ao mesmo tempo, perguntou-lhe se não poderia dar-se ao trabalho de falar a Roeber sobre a mudança da data do combate.

O diretor escutou-o de perfil, a olhar para uma janela. Ao certificar-se de que o atleta terminara, virou para ele os olhos duros, de sob os quais pendiam papos terrosos, e atalhou, curto e grosso:

- Cem rublos de multa.

- Senhor diretor...

- Com os diabos, eu sei muito bem que eu sou o senhor diretor - interrompeu-o, começando a exaltar-se. - Arranje-se com Roeber o senhor próprio, eu não tenho nada com isso. O meu negócio é o contrato, o seu, a multa.

Deu as costas a Arbúzov abruptamente e precipitou-se rumo à porta, a coxear de uma perna de cada vez, mas, diante dela, estacou repentinamente, voltou-se e, a estalar de raiva, com as faces flácidas trementes, o rosto rubro, o pescoço inflado e os olhos arregalados, começou a gritar, esbaforido:

- Com os diabos! Está a morrer o Fatinitsa, o primeiro cavalo em corridas com obstáculos!... Um cocheiro russo, um canalha, um porco, um macaco russo deu de beber em excesso ao melhor cavalo, e o senhor acha ainda de vir pedir um monte de tolices. Com os diabos! Hoje é o último dia desse carnaval russo idiota, e me faltam até cadeiras suplementares, e o publicum vai-me fazer ein grosser Scandal (13), se eu cancelar a luta. Com os diabos! Exigirão o dinheiro de volta de mim e quebrar o meu circo em pedacinhos! Schwamm drüber! (14). Eu não quero ouvir tolices, não ouvi nada e não sei de nada!

Ele se precipitou da cantina em um salto, batendo a porta atrás de si com tanta força, que os copos do balcão até soltaram um tilintar leve e vibrante.
Após despedir-se de Antonio, Arbúzov foi para casa. Era preciso almoçar e tentar dormir bem até a luta, para refrescar um pouco a cabeça. Ao sair do circo, porém, novamente sentiu-se doente. $\mathrm{O}$ barulho e a agitação da rua passavam-se algures, longe-longe dele, e pareciam-lhe alheios, irreais, como se examinasse um quadro multicolorido movente. A atravessar as vias, experimentava um medo pungente de ser atropelado por trás por cavalos e lançado ao chão.

Ele morava perto, em uma pensão. Ainda na escada, sentiu o cheiro, que havia sempre nos corredores: de cozinha, fumo de querosene e ratos. Encaminhando-se ao seu quarto, às apalpadelas, pelo passadiço escuro, esperava bater a qualquer momento em algum obstáculo, e a esse sentimento de tensa expectativa juntavam-se a tristeza, o desnorteamento, o medo e a consciência da sua solidão.

Não lhe apetecia comer mas, quando de baixo, da copa do "Évrik", lhe trouxeram o almoço, obrigou-se a tomar algumas colheradas de borchtch vermelho (15), o qual sabia a trapo sujo de cozinha, e metade de uma almôndega clara, de carne fibrosa, com molho de cenoura. Após a refeição, veio-lhe vontade de beber. Mandou um menino comprar kvas (16) e deitou-se.

No mesmo instante, pareceu-lhe que o leito oscilava levemente e se movia sob ele, como um barco, ao passo que as paredes e o teto deslizavam lentamente para o lado oposto. Mas, em tal sensação, não havia nada de terrível ou desagradável; pelo contrário, no corpo penetrava um langor morno de cansaço e modorra, cada vez mais forte. O teto defumado, sulcado de rachaduras finas e sinuosas, qual veias, ora subia para longe, ora descia para bem perto, e havia, nas suas oscilações, uma suavidade relaxante e sonolenta.

Algures, no quarto contíguo, pessoas tilintavam taças; passos apressados, abafados pela passadeira, iam e vinham pelo corredor, e o bulício da rua entrava amplo e vago pela janela. Durante longo tempo, todos esses sons enleavam-se, antecipavam-
13 Um grande escândalo (al.)

14 Que vá para o diabo que o carregue! (al)

15 Borchtch: sopa de beterraba e couve.

16 Kvas: refresco fermentado de pão de centeio. 
se uns aos outros, baralhavam-se e, de repente, ao fundirem-se por alguns instantes, alinhavam-se em maravilhosa melodia, tão plena, inesperada e bonita, que alargava o peito de doçura e suscitava vontade de sorrir.

Soerguendo-se na cama, para matar a sede, Arbúzov circunvagou os olhos pelo quarto. Na espessa penumbra lilás do entardecer invernal, a mobília pareceu-lhe de todo diferente da que se acostumara a ver: havia, nela, uma expressão estranha, misteriosa, viva. A cômoda baixinha, achaparrada e séria, o armário alto e estreito, de aparência ativa mas insensível e zombeteira, a mesa redonda bonachona e o espelho ataviado, garrido - todos eles o espreitavam de modo perscrutador, expectante e ameaçador, através daquela modorra de langor e preguiça.

"Quer dizer, estou com febre" - pensou Arbúzov e repetiu em voz alta: - Estou com febre. - A voz repercutiu, aos seus ouvidos, vinda de um sítio distante, qual som débil, vazio e indiferente.

Sob o balouço da cama, com agradável e sonolenta dor cortante nos olhos, caiu em delírio febril intermitente, agitado. Mas, no desvario, como em plena consciência, provava a mesma mudança alternada de sensações. Ora parecia-lhe que, com esforços medonhos, removia blocos de granito de lados polidos, lisos e duros ao contato mas que, ao mesmo tempo, cediam macios à pressão das mãos, como algodão, e que os amontoava. Depois, esses blocos caíam e rolavam para baixo, ao passo que, no seu lugar, ficava algo uniforme, instável e sinistramente calmo; isso não tinha nome, mas parecia igualmente tanto a superfície lisa de um lago, quanto um fio de arame, que, retesando-se infinitamente, zunia de modo monótono, extenuante e sonolento. Mas o arame desaparecia; Arbúzov outra vez entrava a levantar blocos imensos, outra vez eles caíam com estrondo, e, no mundo inteiro, outra vez restava tão-somente o sinistro, maçante arame. Ao mesmo tempo, Arbúzov não deixava de ver o teto com rachaduras e ouvir os sons estranhamente entrelaçados, mas tudo isso pertencia a um mundo alheio, que o espreitava com hostilidade, um mundo lastimável e desinteressante, se comparado às alucinações, em que ele vivia.

Estava já completamente escuro, quando Arbúzov se ergueu de repente, em um salto, e se sentou na cama, pungido por um medo atroz e por uma tristeza física insuportável, a qual começava no coração, então parado, enchia todo o peito, subia à garganta e a apertava. Faltava ar aos pulmões; de dentro, algo o impedia de entrar. Arbúzov abria a boca convulsivamente, tentando respirar, mas não sabia fazê-lo nem o conseguia, e sufocava. Essas sensações terríveis não duraram nada mais de dois ou três segundos, mas ao atleta pareceu que o ataque começara muitos anos antes e que ele envelhecera nesse tempo. "A morte está a caminho!" - passou-lhe, de repente, pela cabeça, mas, nesse momento, a mão invisível de alguém tocou o coração parado, como se toca um pêndulo imóvel, e ele, após uma sacudida doida, prestes a arrebentar o peito, pôs-se a bater assustada, ávida e atabalhoadamente. Simultaneamente, tépidas ondas de sangue precipitaram-se para o rosto, mãos e pés de Arbúzov e cobriram todo o seu corpo de suor.

Pela porta aberta, introduziu-se uma cabeça grande e tosada, com orelhas finas, de abano, como asas de morcego. Era Grichútka (17), empregadinho da pensão, que passava para saber se Arbúzov desejava chá. De trás dele, de maneira alegre e alentadora, esgueirou-se para o quarto a luz da lâmpada do corredor.

- Ordena o samovarzinho, Nikit Iónitch? (18)

Arbúzov ouviu bem essas palavras, e elas se gravaram na sua memória, mas ele não conseguia de modo algum compreender o seu significado. Naquele momento, o seu pensamento trabalhava intensamente, na tentativa de captar uma palavra extraordinária, rara e muito importante, que ouvira em meio ao sono, antes de erguer-se da cama em um salto, antes do ataque.

— Nikit Iónitch, é para trazer o samovar, hem? Passa já das seis.

- Espera, Gricha (19), espera, já-já respondeu Arbúzov, a ouvir o menino mas ainda sem compreendê-lo, e de repente apanhou a palavra esquecida: "bumerangue". 
Isso é um pedaço de madeira recurvado e engraçado, que uns selvagens negros, homenzinhos nus, ágeis e musculosos, lançavam ao ar, no circo de Montmartre. Imediatamente, tal como se libertada de peias, a atenção de Arbúzov transferiu-se para as palavras do menino, que lhe soavam ainda na memória.

- Dizes que passa já das seis? Pois, então, traz o samovar depressa, Gricha.

Foi-se o menino. Arbúzov ficou largo tempo sentado na cama, com os pés no chão, e, a olhar para os cantos escuros, aplicava o ouvido ao coração, que batia ainda inquieto e agitado. Entrementes, os lábios moviamse ligeiramente, a repetir distintamente sempre a mesma palavra sonora e elástica, que o aturdira:

- Bu-me-ran-gue!

IV

Pelo beirar das nove horas, Arbúzov foi para o circo. Acompanhava-o o menino cabeçudo, ardoroso apreciador da arte circense, levando a sacola de palha, em que estava o uniforme de lutador. À entrada, iluminada festivamente, havia alegre bulício. Um após outro, ininterruptamente, aproximavam-se cocheiros e, a um sinal de um guarda majestoso qual estátua, afastavam-se, fazendo um semicírculo, rumo à escuridão, em que se alinhavam carruagens e trenós em comprida fila, ao longo da rua. Viam-se os cartazes vermelhos do circo e os anúncios verdes da luta em toda parte - em ambos os lados da entrada, ao pé das bilheterias, no vestíbulo e nos corredores; em todos os lugares, Arbúzov via o seu sobrenome impresso em letras garrafais. Nos passadiços, sentia-se o cheiro das cavalariças, de gás, da areia e da serradura do picadeiro, e o cheiro habitual das salas de espetáculos: misto de luvas de pelica e póde-arroz. Tais odores, que, nas noites anteriores, sempre excitavam Arbúzov e o estimulavam, naquela, resvalaram de modo mórbido e desagradável pelos seus nervos.

Nos bastidores, junto à passagem pela qual os artistas entram em cena, estava afixado o programa da noite, escrito à mão e iluminado por um bico de gás, com os cabe- çalhos impressos: "Arbeit. Pferd. Klown" (20). Arbúzov olhou para ele com vaga e ingênua esperança de não encontrar ali o seu nome. Na segunda parte, porém, na frente da palavra Kampf (21), conhecida dele, estavam dois apelidos, escritos com caligrafia grande, em declive, de pessoa semi-analfabeta: Arbouzow e Roeber.

$\mathrm{Na}$ arena, gritavam palhaços, com voz inexpressiva, velarizando o "r" e o "l", e gargalhavam de modo idiota. Antonio Batista e sua esposa Henrietta, na passagem, esperavam pelo fim do número. Ambos usavam um traje de tricô, de cor violeta suave, bordado com lantejoulas douradas, que, a contra luz, tinha um brilho cambiante de seda nas dobraduras, e sapatos brancos, de cetim.

Henrietta não trazia saia; em lugar desta, da cintura pendia-lhe longa e espessa franja, reverberante a cada movimento seu. A camisola de cetim, vestida diretamente sobre o corpo, sem espartilho, era-lhe folgada e não tolhia os movimentos do torso flexível. Sobre a malha, a moça pusera um burnus árabe branco e comprido, que lhe realçava levemente a cabecinha bonita, os cabelos negros e a tez morena.

— Et bien, monsieur Arbousoff? (22) perguntou Henrietta, sorrindo carinhosamente e estendendo-lhe a mão nua, fria mas forte e bonita, de sob o albornoz. - Que lhe parecem as nossas novas vestimentas? Isto foi idéia do meu Antonio. Irá ao picadeiro assistir à nossa apresentação? Por favor, vá. Tem bom olho e me trará sorte.

Antonio abeirou-se e deu tapinhas amistosos no ombro de Arbúzov.

- Então, como vão as coisas, meu flór? All right! (23). Eu apostei uma garrafa de conhaque em você, com o Vincenzo. Olhe lá, hem!

Pelo circo, reboou um riso, e estalaram os aplausos. Dois palhaços, com os rostos untados com tintas branca e carmesim, irromperam no corredor. Eles como que esqueceram os sorrisos largos e estúpidos na face, mas, após os exaustivos saltos mortais, os seus peitos respiraram fundo e rápido. Chamaram-nos de volta ao picadeiro e obrigaram-nos a fazer mais alguma coisa, depois, novamente e mais uma vez; apenas
20 Trabalho. Cavalo. Palhaço (al.).

21 Luta (al.)

22 Que tal, senhor Arbúzov? (fr.).

23 Muito bem! (ing.). 
quando a orquestra começou a tocar uma valsa e a platéia se aquietou, os dois puderam ir para os camarins, ambos suados, abatidos e derreados de cansaço.

Os artistas não incluídos na função daquela noite, de casaca e calças com bandas douradas, baixaram rápida e agilmente uma rede grande do teto, que haviam atado a mastros com cordas. Em seguida, alinharam-se de ambos os lados da passagem, e alguém descerrou a cortina. Após lançar um olhar carinhoso e faceiro de sob as sobrancelhas finas e intrépidas, Henrietta arrancou de si o burnus e atirou-o a Arbúzov; com o movimento feminino costumeiro, consertou o cabelo e, de mão dada com o marido, correu graciosamente para a arena. Arbúzov entregou a veste a um cavalariço e seguiu-os.

Todos os integrantes da companhia gostavam de ver o trabalho do casal. Além da beleza e leveza dos movimentos, impressionava-os o sentido do ritmo, levado a uma precisão extraordinária - um sexto sentido, especial, dificilmente compreensível em outro lugar, que não o balé e o circo, mas indispensável em todos os movimentos difíceis e coordenados sob música. Sem perderem um segundo sequer, Antonio e Henrietta subiram lestamente quase até ao teto, à altura das fileiras superiores da galeria. Dos vários extremos do circo, enviavam beijos ao público: ele, sentado em um trapézio; ela, de pé sobre um mocho leve, revestido com o mesmo cetim violeta da sua camisa, com uma franja dourada nas beiradas e as iniciais A e V no centro.

Tudo que faziam era simultâneo, coordenado e, aparentemente, tão leve e simples, que até os outros artistas, de olhos fitos neles, perdiam a noção da dificuldade e do perigo daqueles exercícios. Atirando o corpo para trás, como se fosse cair na rede, Antonio de repente pendurava-se de cabeça para baixo e, preso à barra de aço pelas pernas, começava a balançar-se. Henrietta, de pé sobre a sua eminência violeta, a segurarse ao trapézio com os braços estendidos, seguia, tensa e expectante, os movimentos do marido e, de repente, ao apanhar-lhes o ritmo, voava do mocho, com um impulso po inteiro arqueado e as bonitas pernas bem esticadas para trás. O seu trapézio era duas vez mais longo e executava oscilações duas vezes maiores; por isso, os movimentos dos dois ora transcorriam paralelamente, ora os aproximavam, ora os afastavam...

A um sinal imperceptível aos outros, ela largava a barra do seu trapézio, voava para baixo, não segura por nada, e, quando as suas mãos tocavam as de Antonio, eles se agarravam pelos pulsos. Durante alguns segundos, os seus corpos, unidos em um único corpo flexível e forte, balouçavam-se no ar, em movimento suave e largo, e os sapatinhos de cetim de Henrietta roçavam a rede, de bordas levantadas; em seguida, Antonio a virava e atirava aos ares, bem no momento em que, sobre a cabeça dela, passava o outro trapézio, a cuja barra ela se agarrava rapidamente, para, com um único impulso, transladar-se ao outro extremo do circo, ao mocho violeta.

O último exercício da sua apresentação era o salto de grande altura. Com auxílio das roldanas, os estribeiros elevaram o trapézio, com Henrietta sentada nele, até quase a cúpula do circo. Ali, a sete braças do solo, a artista passou cuidadosamente para a barra fixa, quase a tocar os vidros da clarabóia com a cabeça. Arbúzov olhava para ela, a levantar o queixo com esforço, e pensava que, visto lá de cima, Antonio devia parecer bem pequenininho à esposa, e tal pensamento provocava-lhe tontura.

Ao ver Henrietta devidamente instalada na barra, Antonio pendurou-se novamente de cabeça para baixo e começou a balouçarse. A orquestra, que até então tocara uma valsa melancólica, interrompeu-a abruptamente. Ouvia-se apenas o monótono, queixoso chiado do carvão nos lampiões elétricos. Sentia-se lúgubre tensão no silêncio, baixado de súbito sobre os milhares de pessoas, que seguiam, com avidez e temor, cada movimento dos artistas...

- Pronto! (24)-gritou Antonio de modo cortante, resoluto e alegre, e atirou para baixo, para a rede, o lenço branco, com o qual até então, sem parar de balouçar-se para frente e para trás, estivera a esfregar as mãos. Arbúzov viu o modo nervoso, rápido e 
expectante como, a essa exclamação, Henrietta, de pé, sob a cúpula do circo, segura aos cabos com ambas as mãos, foi com todo o corpo para a frente.

- Attenti! (25) - novamente gritou Antonio.

Nos lampiões, o carvão puxava a mesma nota queixosa, monótona, ao passo que, no circo, o silêncio se tornava penoso e ameaçador.

— Allez! (26) - soou, entrecortada e imperiosa, a voz de Antonio.

Esse grito imperioso pareceu abater Henrietta da barra fixa. Arbúzov viu algo grande e violeta, reverberante de faíscas douradas, cair de ponta-cabeça e girar, riscando o ar como um raio. Com o coração gelado e a sensação de súbito enfraquecimento nas pernas, a qual o irritava, o atleta fechou os olhos e abriu-os somente quando, em seguida ao grito alegre, agudo e gutural de Henrietta, o circo inteiro soltou um suspiro ruidoso e profundo, como gigante, que houvesse arriado pesada carga das costas. A orquestra começou um galope frenético, e Henrietta, a balançar-se ao seu ritmo, segura pelas mãos de Antonio, agitava alegremente as pernas, uma de cada vez, e batia um pé no outro. Lançada pelo marido à rede, afundou muito e maciamente nela, mas, ao ser atirada de rijo de volta para o ar, pôs-se de pé imediatamente e, equilibrando-se no tremedal de fios, toda radiante em um sorriso sincero, enrubescida e encantadora, fazia reverências ao público, que gritava... Pondo o burnus sobre ela, nos bastidores, Arbúzov notou-lhe o arfar intenso do peito e o latejar forte de duas vênulas azuis nas têmporas...

\section{V}

A sineta deu o sinal do entreato, e Arbúzov foi vestir-se. Roeber mudava de roupa no camarim contíguo. As largas frestas do tabique, feito às pressas, permitia ver cada movimento seu. $\mathrm{O}$ estadunidense ora cantarolava com voz de baixo em falsete, ora assobiava, e a trechos trocava, com o treinador, palavras breves, entrecortadas, as quais soavam de modo tão estranho e surdo, que pareciam sair das profundezas do seu estômago. Arbúzov não sabia inglês, mas, sempre que Roeber se ria ou quando a entonação das palavras se tornava zangada, tinha a impressão de que a conversa era sobre ele e a luta, e, aos sons daquela voz segura, coaxante, tomava-se por um medo e uma sensação de debilidade física cada vez mais fortes.

Ao tirar a roupa de cima, sentiu frio e começou a tremer intensamente, com calafrios febris, que lhe provocavam estremecimento das pernas, do ventre e dos ombros, e fazia os maxilares baterem ruidosamente. Para aquecer-se, mandou Grichutka ir à cantina comprar conhaque. A bebida acalmou-o e aqueceu-o um pouco, mas, após ela, tal qual de manhã, leve e sonolento cansaço espalhou-se pelo seu corpo inteiro.

A cada minuto, batiam à porta e entravam. Eram oficiais de cavalaria, com calções de montar colantes, como que de meia; ginasianos grandalhudos, com gorros estreitos e engraçados, e todos, por alguma razão, com nasóculos e cigarros nos lábios; estudantes tafuis, que falavam muito alto e se tratavam por diminutivos. Todos eles tocavam os braços, o peito e o pescoço de Arbúzov, a admirar o aspecto dos seus músculos tensos. Alguns lhe davam palmadinhas carinhosas e aprovativas nas costas, como a um cavalo vencedor de prêmio, e conselhos sobre como conduzir a luta. A Arbúzov, as suas palavras ora soavam de um sítio distante, subterrâneo, ora avançavam de súbito para ele e batiam-lhe na cabeça, provocando-lhe dor insuportável. Entrementes, ele se vestia, com movimentos maquinais, costumeiros, ajeitando a fina roupa de meia sobre o corpo e esticando-a com apuro, e arrochava fortemente o largo cinto de couro na barriga.

A orquestra começou a tocar, e os incômodos visitantes foram-se, um a um... Ficou apenas o doutor Lukhovítski. Ele pegou a mão de Arbúzov, tateou-lhe o pulso e abanou com a cabeça:

- Lutar será verdadeira insânia. O pulso está como um martelo, e as mãos, completamente frias. Dê uma espiada ao espelho e veja quão dilatadas estão as pupilas.

Arbúzov olhou-se em um pequeno espelho inclinado que havia sobre a mesa do ca-
25 Atenção! (it.)

26 Em frente! (fr.) - Uma das expressões mais correntes da terminologia do circo antigo era proferida pelo diretor do número ou pelo próprio artista antes do ato mais perigoso e espetacular. 
marim e viu um rosto grande, pálido, indiferente, que lhe pareceu desconhecido.

- Bem, não faz diferença, doutor - disse, com preguiça, e, com o pé sobre uma cadeira, pôs-se a enrolar as correias do calçado na panturrilha.

Alguém, passando à carreira pelo corredor, chamou um de cada vez:

- Monsieur Reuber! Monsieur Arbúzov! Ao picadeiro!

Um langor invencível apoderou-se do corpo de Arbúzov, e veio-lhe vontade de espreguiçar-se doce e longamente, como antes de deitar-se. Em um canto do camarim, estavam amontoados, em desordem, trajes circassianos para a pantomima da terceira parte do programa. A olhar para os trastes, Arbúzov pensou que não haveria coisa melhor, no mundo, do que enfiar-se entre eles, estender-se comodamente e afundar a cabeça naquelas roupas quentes, macias.

-É preciso ir - disse, levantando-se, e suspirou. - Doutor, sabe o que é bumerangue?

- Bumerangue? - perguntou-lhe, por sua vez, o médico, admirado. - Parece que é um instrumento especial, com que os australianos alvejam papagaios. Mas, pensando bem, talvez até nem papagaios... Mas qual é o problema?

- Isso apenas me veio à lembrança... Bem, vamos, doutor.

Ao pé da cortina, na larga passagem de tábuas, amontoavam-se artistas, funcionários e cavalariços; quando Arbúzov surgiu, começaram a murmurar entre si e cederamlhe lugar diante da cortina. Em seguida, aproximou-se Roeber. Evitando olhar-se, os lutadores postaram-se lado a lado, e, nesse instante, a Arbúzov ocorreu, com extraordinária clareza, o pensamento de quão absurdo, inútil, disparatado e cruel era o que ele pretendia fazer dali a poucos minutos. Mas também sabia e sentia que era mantido ali e obrigado a agir daquela maneira por uma força inclemente, sem nome. E ele continuou imóvel, de pé, a olhar para as pesadas pregas da cortina, em uma submissão apática e triste.

—Pronto? - perguntou uma voz de cima, do tablado dos músicos.
— Pronto, podem começar! - responderam de baixo.

Ouviu-se a batida inquieta da batuta do regente, e os primeiros compassos de uma marcha espalharam-se pelo circo, em sons alegres e estimulantes de cobre. Alguém abriu rapidamente a cortina, outro deu palmadinhas no ombro de Arbúzov e ordenou-lhe: “Allez!”. Ombro a ombro, pisando com graça pesada e sobranceira e, como antes, sem olharem um para o outro, os lutadores passaram por entre duas fileiras de artistas, e, do centro da arena, foram para cantos diferentes.

Um dos estribeiros também entrou nela e, colocando-se entre os atletas, anunciou a luta, lendo um papelinho com forte sotaque estrangeiro e muitos erros.

- Teremos, agora, um combate de luta greco-romana entre dois famosos atletas e lutadores, o Sr. John Roeber e o Sr. Arbúzov. As regras da luta são que cada contendor pode agarrar o adversário de qualquer modo, da cintura para cima. Será considerado derrotado o que tocar o chão com as espáduas. Não é permitido arranhar o adversário, agarrar-lhe as pernas, puxar os cabelos e apertar a garganta. Esta é a terceira, decisiva e última luta. $\mathrm{O}$ vencedor recebe um prêmio de cem rublos... Antes do início do combate, os lutadores apertam-se as mãos, como em promessa solene de que a luta será limpa e em conformidade com as regras.

Os espectadores escutavam-no em silêncio tão tenso, atento, que parecia que cada um segurava a respiração. Aquele foi, provavelmente, o momento mais cruciante de toda a noite, o momento de uma espera ansiosa. Os rostos estavam pálidos; as bocas, entreabertas; as cabeças, projetadas para a frente; e os olhos, fitos, com ávida curiosidade, nas figuras dos atletas. Estes estavam de pé e em posição imóvel, sobre a lona, que cobria o picadeiro.

Ambos trajavam roupa de meia preta, graças à qual os seus troncos e pernas pareciam mais finos e mais bem proporcionados do que o eram na realidade, ao passo que os braços descobertos e os pescoços nus afiguravam-se mais maciços e mais fortes. Roeber, com uma perna ligeiramente à frente e uma 
mão na cintura, em postura negligente e confiante, tinha a cabeça derreada para trás e circunvagava os olhos pelas galerias superiores. Sabia, por experiência, que a simpatia do público estaria do lado do adversário, como lutador mais jovem, bonito, elegante e, principalmente, de sobrenome russo, e, com aquele olhar negligente e tranqüilo, parecia lançar um desafio à multidão, que o examinava. Era de estatura mediana, largo nos ombros e ainda mais na direção da pelve, de pernas curtas, grossas e tortas, como raízes de árvore possante, de braços longos, e arqueado como um macaco grande e forte. Tinha cabeça escalvada e pequena, com nuca de touro, que, começando do cocuruto, se transformava, regular e plana, em pescoço, sem quaisquer arqueamentos, do mesmo modo como o pescoço, alargando-se para baixo, se fundia diretamente aos ombros. Essa nuca medonha suscitava, nos espectadores, um pensamento vago e temeroso em uma força sobre-humana, cruel.

Arbúzov, também de pé, assumira a postura habitual, em que os lutadores profissionais sempre saem nas fotografias, isto é, com os braços cruzados sobre o peito e o queixo puxado sobre este. $\mathrm{O}$ seu corpo era mais branco do que o de Roeber, e a compleição, quase impecável: o pescoço sobressaía do decote da roupa de meia como tronco possante, redondo e regular de árvore, e, sobre ele, com desenvoltura e leveza, repousava uma cabeça bonita e arruivascada, com cabelos bem aparados, fronte baixa e rosto com traços indiferentes. Os músculos do peito, contraídos pelos braços cruzados, delineavam-se, sob a roupa, como dois montículos salientes, e os ombros abaulados cobriam-se de um lustro de cetim róseo, sob o resplendor azul dos lampiões elétricos.

Arbúzov olhava fixamente para o estribeiro. Desviou os olhos dele apenas uma vez, deitando-os na platéia. O circo inteiro, lotado de cima a baixo, estava como que coberto por densa onda negra, sobre a qual, amontoando-se uma sobre outra, distinguiam-se, em filas regulares, as manchas brancas dos rostos. Arbúzov sentiu o hálito frio, inclemente e fatal daquela massa negra, in- forme. Com todo o seu ser, compreendeu que, para ele, não haveria saída daquele círculo vicioso intensamente iluminado, que a vontade imensa de alguém o levara até ali e que força nenhuma conseguiria tirá-lo dali. Por causa desse pensamento, sentiu-se, de repente, desamparado, desconcertado e fraco, qual criança perdida, e, na sua alma, revolveu-se verdadeiro medo animal, o obscuro, instintivo terror, que deve apossar-se do jovem touro, quando o levam ao abatedouro pelo asfalto coberto de sangue.

$\mathrm{O}$ estribeiro concluiu a leitura e foi para a saída. A música recomeçou nítida, alegre e cautelosa, e, nos sons estrídulos dos cornetins de chaves, ouvia-se um triunfo malicioso, oculto e cruel. Houve um momento terrível, no qual a Arbúzov pareceu que esses sons insinuantes da marcha, o chiado triste do carvão e a mudez lúgubre dos expectadores serviam de continuação do seu delírio de depois do almoço, no qual vira o longo e monótono fio de arame, estendido diante dele. No seu espírito, novamente, alguém gritou o nome do instrumento australiano.

Até então, porém, Arbúzov afagava ainda a esperança de que, no último momento, antes da luta, como sempre soía acontecer, nele de repente se desencadeasse a raiva e, com ela, a confiança na vitória e rápido afluxo de força física. Mas, quando os dois se voltaram um para o outro e Arbúzov encontrou, pela primeira vez, a mirada fria e penetrante dos pequenos olhos azuis do adversário, ele compreendeu que a luta estava já decidida.

Caminharam um em direção ao outro. Roeber aproximou-se a passos rápidos, macios e leves, com a terrível nuca inclinada para a frente, a dobrar levemente as pernas, à semelhança de um animal predador, que pretendesse dar um bote. Ao encontraremse no meio da arena, trocaram rápido e forte aperto de mão, apartaram-se e imediatamente puseram-se de frente um para o outro, com saltos simultâneos. No toque descontínuo da quente, forte, calejada mão de Roeber, Arbúzov sentiu a mesma certeza da vitória, que lhe vira nos olhos espetantes.

No início, tentaram agarrar-se pelas mãos, cotovelos e ombros, a escapar dos 
agarrões e a esquivar-se destes. Os seus movimentos eram lentos, suaves, cautelosos e calculados, como os de dois gatos grandes, que houvessem começado a brincar. Com as têmporas encostadas, a soltarem o bafo quente da respiração um no ombro do outro, trocavam constantemente de lugar e deram uma volta à arena. Arbúzov, aproveitando-se da sua maior estatura, envolveu a nuca de Roeber com a palma da mão e tentou fazê-lo arquearse, mas a cabeça do estadunidense, rápida como a da tartaruga, que se esconde, encravou-se entre os ombros, o pescoço ficou duro, como se fosse de aço, ao passo que as pernas, bem abertas, se firmaram rijamente no chão. Ao mesmo tempo, Arbúzov sentiu que Roeber apertava com toda a força os seus bíceps, para causar-lhe dor e tirar-lhe rapidamente a força.

Percorreram a arena toda assim, a moverse com dificuldade e sem se largarem, com movimentos lentos, como se preguiçosos e hesitantes. De repente, Roeber, agarrando um braço de Arbúzov com ambas as mãos, puxou-o para si com força. Arbúzov, que não previra a investida, deu dois passos à frente e, no mesmo segundo, sentiu que por trás o cingiram e levantaram do chão dois braços fortes, cruzados sobre o seu peito. Instintivamente, inclinou o tronco para a frente, para aumentar o peso, e abriu bem os braços e as pernas, para o caso de um ataque. Roeber fez vários esforços para trazer as costas de Arbúzov para o seu peito; vendo que não conseguiria levantá-lo, obrigou-o, com um tranco, a pôr-se de quatro e, agarrando-o pelo pescoço e costas, ajoelhou-se ao lado dele.

Durante algum tempo, pareceu meditar e ajeitar-se. Depois, com hábil movimento, enfiou um braço, por trás, pelo sovaco de Arbúzov, dobrou aquele para cima, deitou a mão áspera e fria no seu pescoço e pôs-se a arquear este para baixo; com o outro braço, apertava-lhe a barriga e tentava fazer o seu corpo girar sobre a cabeça. Arbúzov resistia, a retesar o pescoço, a abrir mais os braços e a agachar-se mais ainda. Os lutadores não se moviam do lugar, como que inteiriçados naquela posição, e outra pessoa poderia pensar que estavam a brincar ou a descansar, se não fosse possível ver como os seus rostos e pescoços iam ficando vermelhos e como os seus músculos tensos sobressaíam cada vez mais de sob a roupa de tricô. A sua respiração era ruidosa e difícil, e o cheiro forte do seu suor sentia-se nas primeiras filas da platéia.

De repente, a conhecida tristeza física de antes cresceu perto do coração de Arbúzov, encheu-lhe todo o peito, apertou-lhe convulsivamente a garganta, e tudo se tornou imediatamente tedioso, vazio e indiferente para ele: os sons de cobre da música, o canto triste dos lampiões, o circo, Roeber e a própria luta. Algo do tipo de um hábito antigo obrigava-o ainda a resistir, mas, na respiração entrecortada do adversário, a qual sentia na nuca, ouvia já sons roucos, semelhantes aos rugidos triunfantes de uma fera, e uma das suas mãos, arrancada do chão, procurava já, inutilmente, apoio no ar. Em seguida, todo o seu corpo também perdeu o equilíbrio, e ele, inesperada e fortemente apertado à lona fria, viu, acima de si, o rosto suado de Roeber, de bigodes emaranhados, os dentes arreganhados, os olhos deformados pela loucura e o ódio...

Quando se pôs em pé, Arbúzov viu Roeber como que através de uma névoa; o outro fazia reverências ao público em várias direções. Os espectadores, que haviam saltado dos lugares, gritavam freneticamente, moviam-se, agitavam lenços, mas tudo aquilo pareceu a Arbúzov um sonho já conhecido de muito um sonho absurdo, fantástico e, ao mesmo tempo, mesquinho e tedioso, em comparação com a tristeza, que lhe despedaçava o peito. A cambalear, chegou a custo ao camarim. $\mathrm{O}$ aspecto dos trastes amontoados recordou-lhe algo vago, em que pensara pouco tempo antes, e ele se deixou cair sobre o monte de roupas, com as mãos apertadas ao peito, sobre o coração, a respirar de boca aberta.

Subitamente, junto com a tristeza e a perda da respiração, dele se apoderaram a náusea e a fraqueza. Enverdeceu tudo aos seus olhos, depois, começou a escurecer e sumirse em fundo precipício negro. No seu cérebro, qual som alto e cortante - como se ali se houvesse rompido uma corda fina - alguém gritou clara e distintamente: bu-me-ran-gue! Depois, sumiu tudo: o pensamento, a consciência, a dor, a tristeza. E isso foi tão simples e tão rápido como se alguém houvesse soprado uma vela em quarto escuro... [1902] 